\title{
Growth and Nutrients Content and Uptake of Garlic (Allium sativum L.) as Influenced by Different Types of Fertilizers and Soils
}

\author{
Diriba-Shiferaw $\mathbf{G}^{* 1}$, Nigussie-Dechassa $\mathbf{R}^{1}$, Kebede Woldetsadik ${ }^{1}$, \\ Getachew Tabor ${ }^{2}$ and Sharma JJ ${ }^{1}$ \\ ${ }^{1}$ School of Plant Sciences, Haramaya University, Post Box No: 138, Dire Dawa, Ethiopia \\ ${ }^{2}$ Ethiopian Institute of Agricultural Research, Debre Zeit Agricultural Research Centre, \\ Post Box No: 32, Debre Zeit, Ethiopia
}

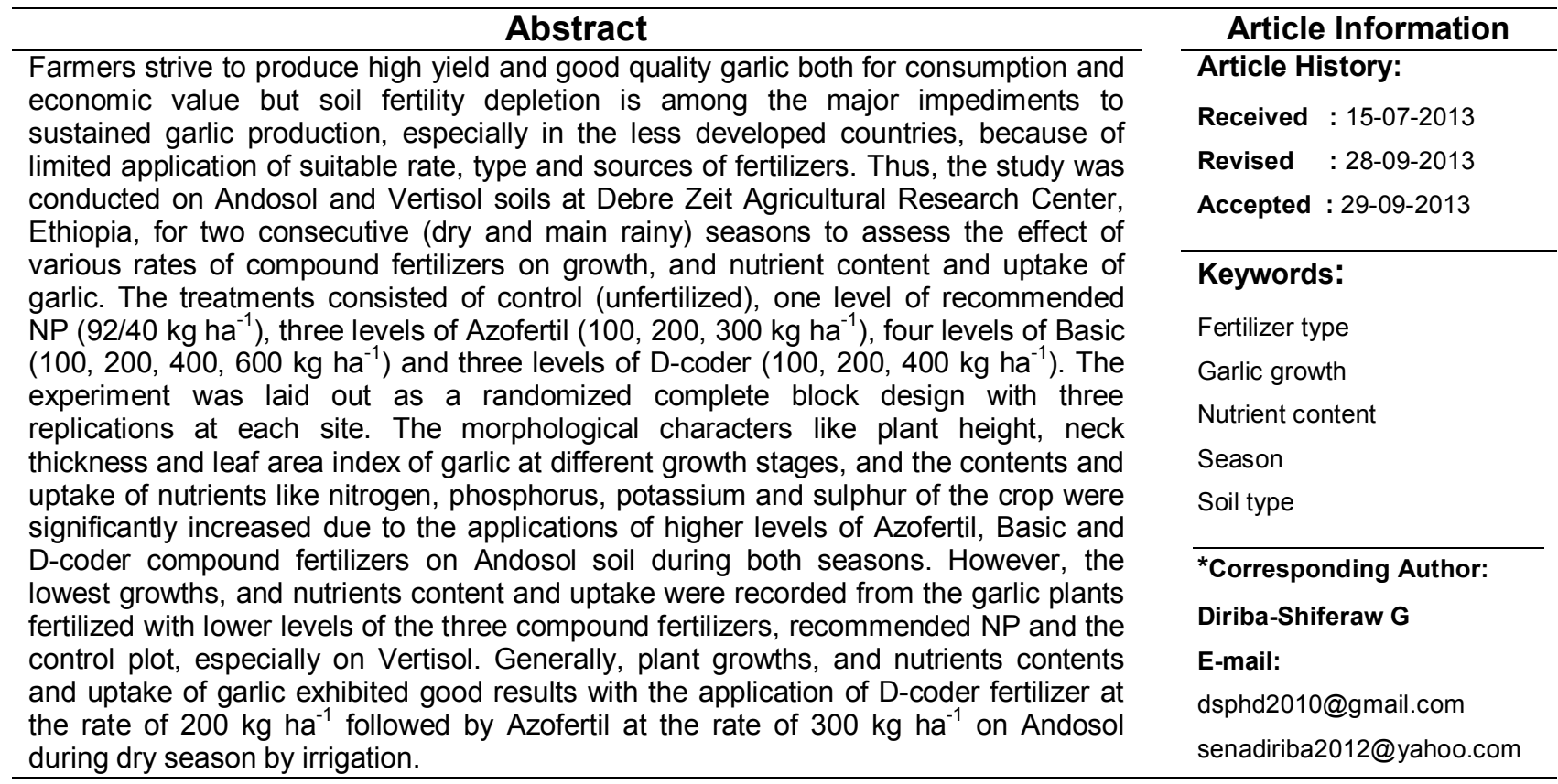

\section{INTRODUCTION}

Garlic is one of the main Allium vegetable crops known worldwide with respect to its production and economic value. It is used as a seasoning in many foods worldwide; without garlic many of our popular dishes would lack the flavor and character that make them favorites. Garlic's volatile oil has many sulfur containing compounds that are responsible for the strong odor, its distinctive flavor and pungency as well as for its healthful benefits (Salomon, 2002). Moreover, it contains considerable amounts of $\mathrm{Ca}, \mathrm{P}$ and $\mathrm{K}$ and its leaves are sources of protein, vitamin A and C (Mahmood, 2000). Garlic has higher nutritive value than other bulb crops in addition to containing antibiotics like garlicin and allistatin (Maly et al., 1998). But the growth and yield of garlic is influenced by different nutrients management and other factors during their production in field.

Despite its importance and increased production, garlic productivity, in many parts of the world, is low due to genetic and environmental factors affecting its yield and yield related traits (Nonnecke, 1989). In many garlic producing areas lack of available nutrients is frequently the limiting factor next to the soil water as their uptake and liberation of $\mathrm{N}, \mathrm{P}$ and 
Diriba-Shiferaw et al.,

$S$ from soil organic matter depends upon availability of water (FAO, 2003). In order to improve garlic production different fertilizers application (type, time and rate) is one of the limiting factors of garlic production that should be considered (Brewster and Butler, 1989) and the production of vigorous sprouts is one of the most important factors of successful garlic production through balanced nutrients applications (Potgieter, 2006). Application of balanced fertilizers is the basis to produce more crop output from existing land under cultivation and nutrient needs of crops is according to their physiological requirements and expected yields (Ryan, 2008).

Today, efforts to obtain higher yields and good quality of garlic have led to the application of various types of fertilizers that have dissimilar concentrations of plant nutrients and therefore affect the growth and yield of the crop differently. Bulb crops are a heavy feeder, requiring optimum supplies of nitrogen, phosphorus, potassium and sulphur and other nutrients which can adversely affect the growth, yield and quality of bulbs under sub-optimal levels in the soil (Gubb and Tavis, 2002). Hence, considering garlic as one of the potential vegetable crop for consumption as well as for market, it is imperative to increase its productivity along with desirable attributes through production management practices and application of other sources of nutrients beyond Urea (38\%) and DAP $(62 \%)$, especially those contains potassium, sulphur and other micro-nutrients (CSA, 2011).

High yield and good quality of garlic can be improved through nitrogen and sulphur application strategies as influenced by the source of $\mathrm{N}$ and $\mathrm{S}$, as well as rates and times (Luo et al., 2000). An increase in sulphur supply is related to an increase in alliin content of leaves and bulbs of garlic (Van den Heever, 2006), whereas nitrogen fertilization is necessary for ensuring successful vegetative growth of garlic (Kakara et al., 2002). Stork et al. (2004) reported that the application of nitrogen along sulphur at an early vegetative (sprouting) stage is useful for the promotion of strong vegetative growth before cold winter months.

Research work has been done on the base of NP in different soil types and in various climatic conditions, but very limited work has been reported on various sources of fertilizers for a certain nutrient. Application of only $\mathrm{N}$ and $\mathrm{P}$ containing fertilizers causes reduction of the quantity of $\mathrm{K}$ and $S$ in most of the soils as there is also evidence of fixation of potassium and leaching of sulphur in different types of soils in addition to mining by different crops as result of continues cultivation of land (Murashkina et al., 2006). Therefore the application of $\mathrm{K}$ and $\mathrm{S}$ and other micronutrients to
Sci. Technol. Arts Res. J., July-Sep 2013, 2(3): 35-50

soils having even fair amounts of $\mathrm{K}$ and $\mathrm{S}$ contents may still show its effect on plants. Mattew et al. (2000) and Havlin et al. (2007) stated that Zinc mineral showed high sensitivity in onions production.

Even though, the total fertilizer use has generally increased recently in Ethiopia, its use is still below the recommended levels and based on traditional practice; garlic growers rely on fertilizer nutrient sources that contain only $\mathrm{N}$ and $\mathrm{P}$, and there is little use of other nutrient sources for production of the crop and absence of $\mathrm{K}, \mathrm{S}$ and other micro-nutrients uses by our farmers, resulting in a steady decline of nutrient levels in the soil (Teklu and Teklewold, 2009). However, the use of sufficient and balanced sources of nutrients to obtain good growth and high yield with good quality garlic plant is an important practice in today's garlic production through addition of new technologically produced compound fertilizers that contains different nutrients in one fertilizer product.

Different fertilizers produced in factory by blending different nutrients is used to replace adding two or more fertilizers to the soils by the crop producers and these are used to supply different nutrients for the crop, save resources and economy of the farmers. Thus, the objective of this study was to differentiate suitable level and type of different compound fertilizers application for growth, and nutrients content and uptake of garlic crop on two soil types in both dry and rainy seasons.

\section{MATERIALS AND METHODS \\ Description of the Experimental Site}

The experiment was conducted at the experimental farm of Debre Zeit Agricultural Research Centre $\left(08^{0} 44^{\prime \prime N}\right.$ latitude, $38^{0} 58^{\prime \prime E}$ longitude, altitude of 1860 m.a.s.l) in central Ethiopia over two soil types twice during off-season by irrigation (first season) and main season by rain (second season) of the years 2011/12 and 2012/13, respectively. The area has mean annual maximum and minimum temperatures of $28 / 26^{\circ} \mathrm{C} \& 10.2 / 9.9$ ${ }^{\circ} \mathrm{C}$, with sub-humid climate type and mean rainfall of about $47 / 98 \mathrm{~mm}$ and relative mean humidity of about $51 / 62 \%$ during off- and main rainy seasons, respectively (Figure 1). Experiment was conducted on two major soil types: light grey volcanic ash soil (andosol) with well drained and good soil physical property; and black soil (vertisol) with high water holding capacity, swelling and shrinking properties. Experimental fields were planted to Tef [Eragrostis tef (Zucc.) Trotter] for the previous two consecutive crop seasons. The physical \& chemical properties of $30 \mathrm{~cm}$ depth of the experimental soils were analysed before planting the cloves following the procedures of Jackson (1967) as indicated in Table 1. 


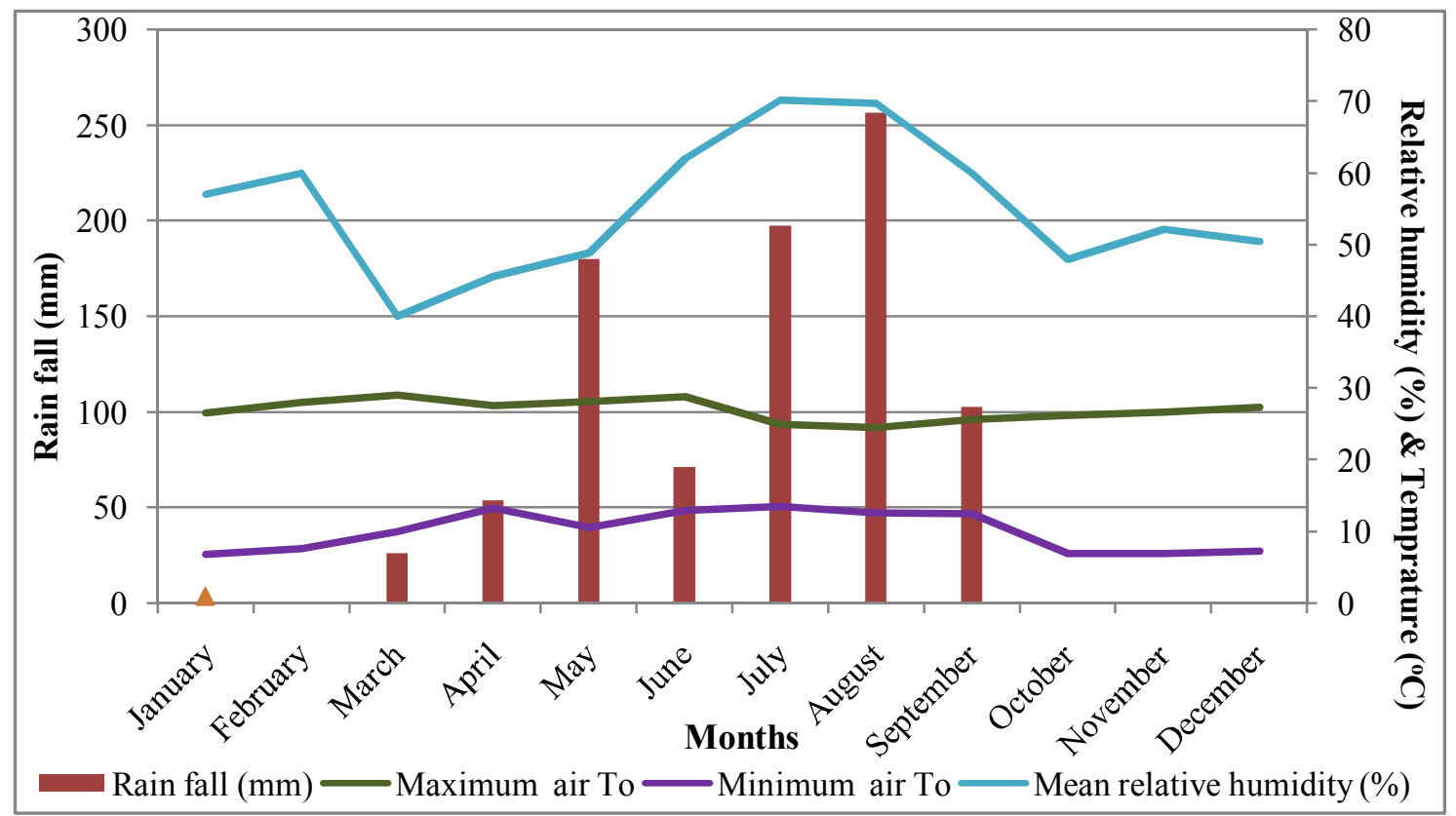

Figure 1: Monthly mean rainfall, relative humidity and maximum and minimum temperatures of year 2011/12 (Off-season: January - May; and Main-season: June - October).

Table 1: Physical \& chemical properties of the experimental soils for two seasons before planting garlic crop

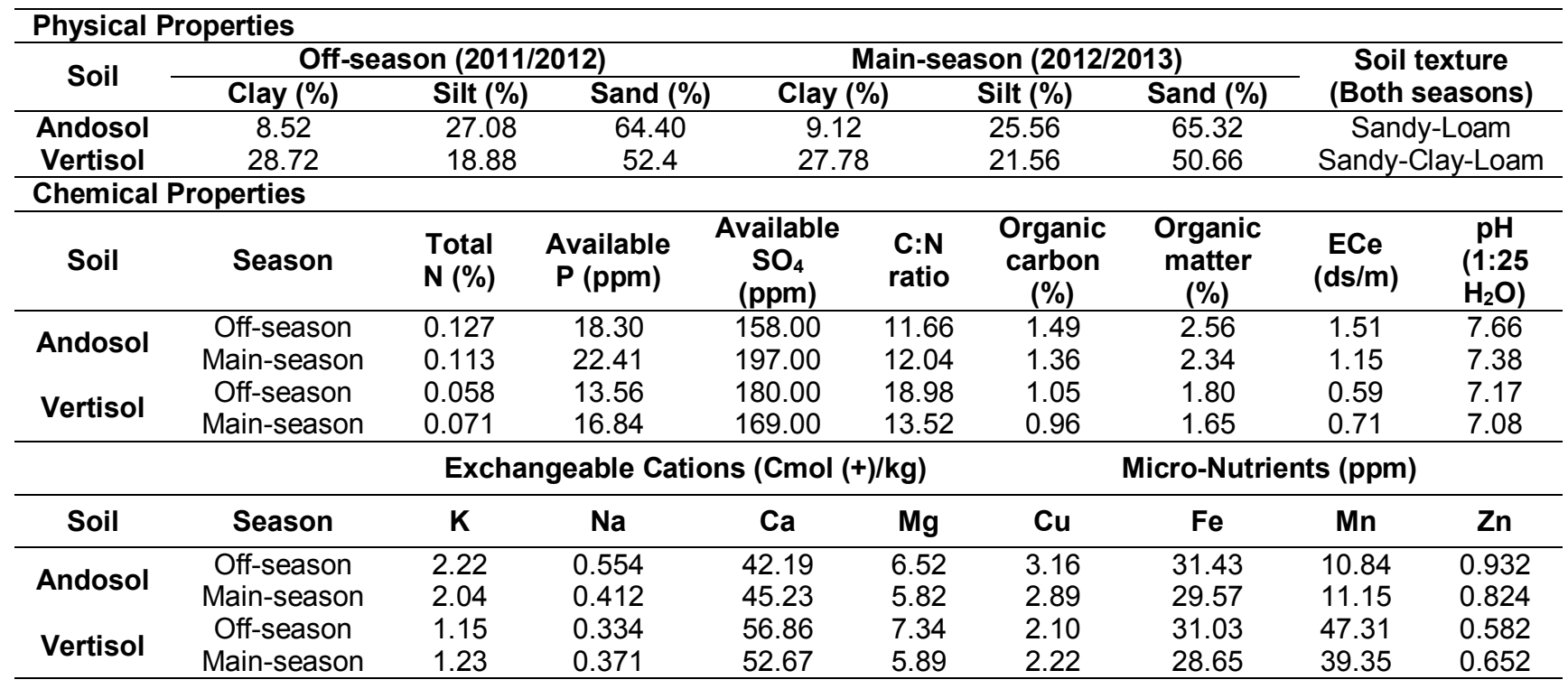

\section{Treatments and Experimental Design}

The treatments were consisting of different compound fertilizers containing different nutrients at different rates except the control and Diammonium phosphate (DAP) or recommended $N$ and $P$ fertilizers (Table 2). Treatments consisted of control (without fertilizer), one level of DAP/NP (92 N+40 P $\left.\mathrm{kg} \mathrm{ha}^{-1}\right)$, three levels of Azofertil $(100,200$ and 300 $\left.\mathrm{kg} \mathrm{ha}^{-1}\right)$, four levels of Basic $(100,200,400$ and 600 $\left.\mathrm{kg} \mathrm{ha}^{-1}\right)$ and three levels of D-coder $(100,200 \& 400$ $\mathrm{kg} \mathrm{ha}^{-1}$ ) fertilizers. Thus, there were 12 fertilizer treatments as indicated in Table 2. The treatments were arranged in a randomized complete block design with three replications

\section{Planting and Agronomic Practices}

Experimental plots were thoroughly pulverized, leveled and ridges of about $20 \mathrm{~cm}$ high were prepared. The crop was planted on the ridge of smoothed soil at the spacing of $30 \mathrm{~cm}$ between rows, $60 \mathrm{~cm}$ between double rows and $10 \mathrm{~cm}$ between plants on both soil types on plot size of 3.6 $\mathrm{m}^{2}(1.8 \mathrm{~m} \times 2 \mathrm{~m})$. A distance of $1 \mathrm{~m}$ was maintained between the plots and $1.5 \mathrm{~m}$ between blocks. In each trial, a garlic variety called "Tseday" was used 


\section{Diriba-Shiferaw et al.,}

for the experiment. Healthy and uniform mediumsized cloves were selected and planted at the depth of $2 \mathrm{~cm}$ on vertisol, and $4 \mathrm{~cm}$ on andosol. The plot size consisted of six rows with 20 plants per row; comprising 120 plants per plot. The rest production management and agronomic practices were kept uniform for all treatments over both soils during both seasons as per the recommendation of Debre Zeit Agricultural Research Centre (Getachew and Asfaw, 2000).
Sci. Technol. Arts Res. J., July-Sep 2013, 2(3): 35-50

The full dose of all compound fertilizers were applied at planting, but urea fertilizer was sidedressed four weeks after emergency of cloves to adjust $\mathrm{N}$ content of DAP at locally used recommended levels of each $\mathrm{N}$ and $\mathrm{P}$ fertilizers (check) as indicated in Table 2. The levels of each compound fertilizer were selected depending on their nutrients content.

Table 2: Treatments of different types of compound fertilizers at different levels.

\begin{tabular}{|c|c|c|c|}
\hline Treatment code & Fertilizer type & Rate (kg/ha) & Compound fertilizers' mineral contents (\%) \\
\hline $\mathrm{C}_{0}$ & 0 & 0 & Control \\
\hline $\mathrm{NP}_{92: 40}$ & $\mathrm{NP}(\mathrm{DAP})$ & $200(92: 40)$ & $\begin{array}{l}\text { Diammonium phosphate (46\%P \& 18\%) + } \\
\text { Urea }(46 \% N)(\text { recommended NP) }\end{array}$ \\
\hline$A_{100}$ & Azofertil & 100 & Azofertil $(30 \% \mathrm{~N}+25 \% \mathrm{~S})$ \\
\hline$A_{200}$ & Azofertil & 200 & $>\quad(60 \% \mathrm{~N}+50 \% \mathrm{~S})$ \\
\hline$A_{300}$ & Azofertil & 300 & $(90 \% N+75 \% S)$ \\
\hline$B_{100}$ & Basic & 100 & Basic $(9 \% N+6 \% P+22 \% K+10 \% C a O)$ \\
\hline $\mathrm{B}_{200}$ & Basic & 200 & $>>(18 \% \mathrm{~N}+12 \% \mathrm{P}+44 \% \mathrm{~K}+20 \% \mathrm{CaO})$ \\
\hline $\mathrm{B}_{400}$ & Basic & 400 & $>>(36 \% N+24 \% P+88 \% K+40 \% C a O)$ \\
\hline $\mathrm{B}_{600}$ & Basic & 600 & $>(54 \% \mathrm{~N}+36 \% \mathrm{P}+132 \% \mathrm{~K}+60 \% \mathrm{CaO})$ \\
\hline $\mathrm{D}_{100}$ & D-coder & 100 & $D-\operatorname{coder}(14 \% N+9 \% P+21 \% S+0.1 \% Z n)$ \\
\hline$D_{200}$ & D-coder & 200 & $>\quad(28 \% N+18 \% P+42 \% S+0.2 \% Z n)$ \\
\hline$D_{400}$ & D-coder & 400 & $>\quad(56 \% N+36 \% P+84 \% S+0.4 \% Z n)$ \\
\hline
\end{tabular}

\section{Data Collection}

Ten sample plants from each plot was randomly tagged from the middle four rows and data recorded on the growth parameters of garlic at successive growth stages of $30,60,90$ and 120 days after cloves planted. Growth parameters measured at different time interval from the sample plants were plant height $(\mathrm{cm})$, leaves number per plant, neck diameter $(\mathrm{mm})$ and leaf area index. Additionally days taken to $50 \%$ emergence of shoots and $90 \%$ physiological maturity of plants were recorded.

Garlic leaves were randomly taken from plants of each plot just before bulbing at an active leaf growth stages. Thirty actively growing leaves from the central point of insertion on the garlic stem were randomly taken from the plants of middle rows. Then, the leaves were oven dried at $65^{\circ} \mathrm{C}$ for 48 hours, weighted and grinded for the analysis of $\mathrm{N}$, $\mathrm{P}, \mathrm{K}$ and $\mathrm{S}$ concentrations in garlic leaf tissues. After matured bulbs were harvested, five clean sample bulbs from each plot were collected randomly, grinded to small size and bulb tissues were oven dried at $65^{\circ} \mathrm{C}$ for 48 hours, then fine grinded and used to determine ion contents on a dry weight basis. Dried sample tissues were wet digested as described by Wolf (1982). Total N was determined using the modified micro Kjeldhal method (Cottenie et al., 1982) and $\mathrm{P}$ by colorimetric method using spectrophotometer (Olsen et al.,
1954). Potassium content was measured using flame photometer method as described by Chapman and Pratt (1982). The sulphur content was determined Turbido metrically using a spectrophotometer method (Singh and Singh, 1999). Tissues nutrient uptake was determined by multiplying their respective dry weights and nutrients concentration obtained within their respective garlic tissues; and the garlic plant nutrients uptake was done as total nutrients taken-up both by leaf and bulb tissues.

\section{Data Analysis}

The mean data were subjected to analysis of variance using SAS (Statistical Analysis System) version 9.0 and mean separation was done using the Fisher's Least Significant Difference at 5\% probability level according to the method described by Snedecor and Cochran (1980).

\section{RESULTS AND DISCUSSION}

\section{Status of Nutrients in the Experimental Soils}

The average of two season's experimental soils' nutrients content was found to be generally larger in andosol than that of vertisol (Table 1). Similarly, the organic matter content of andosol soil was higher than that of vertisol soil in both seasons. The total nitrogen content of the andosol soil $(0.120 \%)$ is low but that of vertisol soil $(0.064 \%)$ is very low (Table 1 ) according to the rating of Hazelton and Murphy 
Diriba-Shiferaw et al.,

(2007), who described that $\mathrm{N}$ content of soil between $0.15-0.25 \%$ is medium and greater than $0.25 \%$ is high. Available phosphorus of both soils is categorized within medium ranges rated by Holford and Cullis (1985) as cited in Hazelton and Murphy (2007). Also the exchangeable potassium contents of the soils of both sites (Table 1) are high according to Hazelton and Murphy (2007). Landon (1991) further stated that a plant response to potassium fertilizer application is likely when a soil has an exchangeable potassium content of lower than $\left.0.20 \mathrm{C} . \mathrm{mol}^{(+}\right) \mathrm{kg}^{-1}$ soil and unlikely when it has exchangeable potassium content of higher than $0.50 \mathrm{C} . \mathrm{mol}(+) \mathrm{kg}^{-1}$ soil. The sulphate-S content of both soils is high according to the rating of Bashour (2001). Zinc content of andosol soil is higher than that of vertisol soil. Also both soil types do not have a salinity problem as the electrical conductivity of both soils are less than the rating described by Hazelton and Murphy (2007) as he reported that soils salinity effect below $2.0 \mathrm{dS} / \mathrm{m}$ is mostly negligible for most of the crops.

\section{Effects of Fertilizers, Season and Soil On Growth Parameters Of Garlic}

Application of different compound fertilizers significantly influenced garlic plant height at all successive growth stages of $30,60,90$ and 120 days after planting (Table 3). But the growths of neck diameter and leaf area index were significantly influenced at 90 and 120 days after planting (Table 4). This indicated that lower influence of fertilizers on the horizontal growth of garlic necks at the initial growth stages but as growth proceeds the applied fertilizer significantly increased the studied growth
Sci. Technol. Arts Res. J., July-Sep 2013, 2(3): 35-50

parameters of garlic as indicated in their respective mean values. This might be due to the allocation of assimilates from plant to the dry matter storage organs of bulbs which at the same time increases the growth of bulb neck. Plant height, neck diameter and leaf area index (LAl) of garlic treated by different levels of fertilizers was significantly increased over the untreated (control) plot at all sampling growth stages, but only application of higher rates of Azofertil (200 and $\left.300 \mathrm{~kg} \mathrm{ha}^{-1}\right)$, Basic (400 and $600 \mathrm{~kg} \mathrm{ha}^{-1}$ ) and D-coder (200 and $400 \mathrm{~kg}$ $\mathrm{ha}^{-1}$ ) fertilizers improved the garlic growths over the recommended NP at maximum growth stages of 90 and 120 days. However, the applied compound fertilizers did not significantly influence the number of days taken to $50 \%$ shoots emergency and $90 \%$ physiological maturity of garlic plant and number of leaves per plant at all growth stages (Table 3). However, the number of leaves per plant was significantly increased as the growth time proceeds in response to the cumulative effect of the applied fertilizers as indicated by their mean values, which indicated that the cumulative role of the nutrients available in the compound fertilizers on the plant development and growth, and this result is in line with the result of Nori et al. (2012), who reported an increased number of leaves and their growths with time. Faten et al. (2010) also revealed that the highest onion plant height and neck diameter growths due to the application of sulphate of potash than muriate of potash, which indicate the positive cumulative effects of two or more nutrients available in the compound fertilizers than the fertilizer containing single element on the growths of the crop.

Table 3: Effect of fertilizer treatments on days to emergency and maturity, plant height and number of leaves at different growth stages of garlic plant.

\begin{tabular}{|c|c|c|c|c|c|c|c|c|c|c|}
\hline \multirow{3}{*}{$\begin{array}{l}\text { Fertilizers } \\
\text { treatments }\end{array}$} & \multirow{3}{*}{$\begin{array}{l}\text { Days to } 50 \% \\
\text { shoots } \\
\text { emergency }\end{array}$} & \multirow{3}{*}{$\begin{array}{l}\text { Days to } 90 \% \\
\text { physiologic } \\
\text { al maturity }\end{array}$} & \multicolumn{4}{|c|}{ Plant Height (cm) } & \multicolumn{4}{|c|}{ Leaf number per plant } \\
\hline & & & \multicolumn{8}{|c|}{ Days after planting (DAP) } \\
\hline & & & 30 & 60 & 90 & & 30 & 60 & 90 & 120 \\
\hline $\mathrm{C}_{0}$ & 13.17 & 131.08 & $24.13^{\mathrm{C}}$ & $41.76^{\mathrm{e}}$ & $46.47^{\mathrm{e}}$ & $48.93^{n}$ & 5.48 & 7.26 & 10.89 & 11.88 \\
\hline $\mathrm{NP}_{92: 40}$ & 13.67 & 131.67 & $25.24^{\mathrm{DC}}$ & $42.83^{\text {de }}$ & $50.44^{\mathrm{ca}}$ & $52.66^{e-g}$ & 5.67 & 7.48 & 11.03 & 11.73 \\
\hline$A_{100}$ & 13.25 & 130.92 & $25.13^{\mathrm{DC}}$ & $42.39^{\mathrm{e}}$ & $50.05^{\mathrm{d}}$ & $51.83^{\mathrm{tg}}$ & 5.66 & 7.62 & 10.63 & 11.48 \\
\hline$A_{200}$ & 13.58 & 130.50 & $25.78^{\mathrm{ab}}$ & $43.85^{\mathrm{b}-\mathrm{a}}$ & $51.79^{\mathrm{b}-\mathrm{d}}$ & $55.06^{\mathrm{DC}}$ & 5.65 & 7.67 & 10.95 & 11.74 \\
\hline$A_{300}$ & 13.17 & 131.58 & $26.08^{\mathrm{ab}}$ & $44.98^{\mathrm{ab}}$ & $52.59^{\mathrm{b}-\mathrm{d}}$ & $53.24^{\mathrm{a}-\mathrm{g}}$ & 5.75 & 7.63 & 11.25 & 11.73 \\
\hline $\mathrm{B}_{100}$ & 12.67 & 131.58 & $26.76^{a}$ & $45.40^{\mathrm{a}}$ & $50.95^{\mathrm{D}-\mathrm{d}}$ & $51.68^{\mathrm{g}}$ & 5.89 & 7.87 & 10.70 & 11.15 \\
\hline $\mathrm{B}_{200}$ & 12.67 & 131.25 & $26.32^{\mathrm{ab}}$ & $44.33^{\mathrm{a}-\mathrm{c}}$ & $52.20^{\mathrm{D}-\mathrm{a}}$ & $54.49^{\mathrm{ca}}$ & 5.71 & 7.57 & 10.50 & 11.42 \\
\hline $\mathrm{B}_{400}$ & 13.42 & 131.50 & $25.01^{\mathrm{DC}}$ & $42.96^{c-e}$ & $51.99^{\mathrm{b}-\mathrm{a}}$ & $56.95^{\mathrm{a}}$ & 5.61 & 7.34 & 10.84 & 11.56 \\
\hline $\mathrm{B}_{600}$ & 12.92 & 132.00 & $25.80^{\mathrm{ab}}$ & $44.38^{\mathrm{a}-\mathrm{c}}$ & $52.03^{\mathrm{D}-\mathrm{d}}$ & $53.98^{c-e}$ & 5.68 & 7.74 & 10.46 & 11.24 \\
\hline$D_{100}$ & 12.75 & 131.25 & $26.01^{a b}$ & $44.11^{\mathrm{a}-\mathrm{a}}$ & $52.80^{\mathrm{DC}}$ & $52.70^{\mathrm{e}-\mathrm{g}}$ & 5.58 & 7.10 & 10.93 & 11.64 \\
\hline$D_{200}$ & 13.33 & 131.67 & $25.15^{\mathrm{Dc}}$ & $43.16^{c-e}$ & $58.00^{\mathrm{a}}$ & $56.46^{\mathrm{ab}}$ & 5.40 & 7.19 & 10.91 & 11.68 \\
\hline $\mathrm{D}_{400}$ & 13.25 & 131.67 & $27.13^{\mathrm{a}}$ & $44.0^{\mathrm{a}-\mathrm{a}}$ & $53.15^{\mathrm{D}}$ & $53.52^{c-t}$ & 5.91 & 7.83 & 10.98 & 11.63 \\
\hline Mean & 13.15 & 131.39 & $25.71^{D}$ & $43.68^{C}$ & $51.87^{B}$ & $53.46^{A}$ & $5.67^{\mathrm{D}}$ & $7.52^{C}$ & $10.84^{\mathrm{B}}$ & $11.57^{A}$ \\
\hline LSD & $\mathrm{ns}$ & $\mathrm{ns}$ & * & ** & ** & ** & ns & ns & ns & ns \\
\hline $\mathrm{CV}(\%)$ & 7.89 & 1.12 & 6.55 & 3.92 & 5.91 & 6.00 & 5.07 & 7.71 & 5.86 & 6.30 \\
\hline
\end{tabular}


Table 4: Effect of fertilizer treatments on neck diameter and leaf area index of garlic at different growth periods.

\begin{tabular}{lllllllll}
\hline \multirow{2}{*}{$\begin{array}{l}\text { Fertilizers } \\
\text { treatments* }\end{array}$} & \multicolumn{3}{c}{ Deck diameter $(\mathbf{m m})$} \\
\cline { 2 - 9 } & $\mathbf{3 0}$ & $\mathbf{6 0}$ & $\mathbf{9 0}$ & $\mathbf{1 2 0}$ & $\mathbf{3 0}$ & $\mathbf{6 0}$ & $\mathbf{9 0}$ & $\mathbf{1 2 0}$ \\
\hline $\mathrm{C}_{0}$ & 3.15 & 4.45 & $7.19^{\mathrm{f}}$ & $8.07^{\mathrm{c}}$ & 1.89 & 4.22 & $6.12^{\mathrm{C}}$ & $8.85^{\mathrm{b}}$ \\
$\mathrm{NP}_{92: 40}$ & 3.38 & 4.72 & $8.62^{\mathrm{e}}$ & $8.76^{\mathrm{b}}$ & 2.18 & 4.96 & $7.67^{\mathrm{ab}}$ & $10.09^{\mathrm{ab}}$ \\
$\mathrm{A}_{100}$ & 3.27 & 4.30 & $8.67^{\mathrm{de}}$ & $8.98^{\mathrm{b}}$ & 2.38 & 4.84 & $7.25^{\mathrm{ab}}$ & $9.70^{\mathrm{ab}}$ \\
$\mathrm{A}_{200}$ & 3.71 & 4.56 & $8.74^{\mathrm{c}-\mathrm{e}}$ & $9.63^{\mathrm{a}}$ & 2.53 & 5.13 & $7.61^{\mathrm{ab}}$ & $10.37^{\mathrm{ab}}$ \\
$\mathrm{A}_{300}$ & 3.65 & 4.74 & $9.40^{\mathrm{a}}$ & $9.46^{\mathrm{a}}$ & 2.51 & 5.45 & $7.72^{\mathrm{ab}}$ & $10.47^{\mathrm{ab}}$ \\
$\mathrm{B}_{100}$ & 3.41 & 4.87 & $8.75^{\mathrm{c}-\mathrm{e}}$ & $8.83^{\mathrm{b}}$ & 2.31 & 4.65 & $6.77^{\mathrm{be}}$ & $8.98^{\mathrm{b}}$ \\
$\mathrm{B}_{200}$ & 3.38 & 4.29 & $8.99^{\mathrm{b}-\mathrm{d}}$ & $9.08^{\mathrm{b}}$ & 2.30 & 5.13 & $7.08^{\mathrm{ac}}$ & $9.40^{\mathrm{ab}}$ \\
$\mathrm{B}_{400}$ & 3.38 & 4.71 & $9.09^{\mathrm{a}-\mathrm{c}}$ & $9.52^{\mathrm{a}}$ & 2.14 & 5.21 & $6.98^{\mathrm{bc}}$ & $9.32^{\mathrm{ab}}$ \\
$\mathrm{B}_{600}$ & 3.34 & 4.74 & $9.16^{\mathrm{ab}}$ & $9.59^{\mathrm{a}}$ & 2.22 & 5.23 & $7.49^{\mathrm{ab}}$ & $9.62^{\mathrm{ab}}$ \\
$\mathrm{D}_{100}$ & 3.53 & 4.59 & $8.49^{\mathrm{e}}$ & $8.74^{\mathrm{b}}$ & 2.42 & 4.98 & $6.99^{\mathrm{bc}}$ & $9.81^{\mathrm{ab}}$ \\
$\mathrm{D}_{200}$ & 3.20 & 4.62 & $9.03^{\mathrm{bc}}$ & $9.60^{\mathrm{a}}$ & 2.38 & 5.62 & $8.07^{\mathrm{a}}$ & $11.29^{\mathrm{a}}$ \\
$\mathrm{D}_{400}$ & 3.59 & 4.76 & $8.76^{\mathrm{c}-\mathrm{e}}$ & $9.61^{\mathrm{a}}$ & 2.46 & 5.29 & $8.03^{\mathrm{a}}$ & $10.58^{\mathrm{ab}}$ \\
\hline Mean & $3.43^{\mathrm{D}}$ & $4.61^{\mathrm{C}}$ & $8.74^{\mathrm{B}}$ & $9.15^{\mathrm{A}}$ & $2.31^{\mathrm{D}}$ & $5.06^{\mathrm{C}}$ & $7.31^{\mathrm{B}}$ & $9.86^{\mathrm{A}}$ \\
\hline LSD & $\mathrm{ns}$ & $\mathrm{ns}$ & $* *$ & ${ }^{* *}$ & $\mathrm{~ns}$ & $\mathrm{~ns}$ & ${ }^{* *}$ & ${ }^{* *}$ \\
\hline $\mathrm{CV}(\%)$ & 10.76 & 13.60 & 4.92 & 7.50 & 24.34 & 19.69 & 15.27 & 9.86 \\
\hline
\end{tabular}

* Fertilizer treatments: $\mathrm{C}_{0}=$ control (unfertilized); $\mathrm{NP}_{92: 40}=$ recommended NP $\left(92: 40 \mathrm{~kg} \mathrm{ha}^{-1}\right) ; \mathrm{A}_{100}, \mathrm{~A}_{200}$ and $\mathrm{A}_{300}=\mathrm{Azofertl}$ at 100 , 200 and $300 \mathrm{~kg} \mathrm{ha}^{-1}$, respectively; $B_{100}, B_{200}, B_{400}$ and $B_{600}=$ Basic at $100,200,400$ and $600 \mathrm{~kg} \mathrm{ha}^{-1}$, respectively; $D_{100}, D_{200}$ and $D_{400}=D$-coder at 100, 200 and $400 \mathrm{~kg} \mathrm{ha}^{-1}$, respectively. Means followed by the same letters within column is not significantly differed; ns $=$ indicate non-significant, and ${ }^{*},{ }^{* *}$, indicate significant at $P<0.05$, and 0.01 LSD tests, respectively

The growths of garlic plant parameters studied increased with time due to the applied fertilizers which indicated that nutrients demand and uptake by the crop increases as the growth of plants proceeds (Tables 3 and 4). The mean values of garlic growth parameters significantly increased with growth periods up to 120 days. D-coder compound fertilizer applied at the rate of $200 \mathrm{~kg} \mathrm{ha}^{-1}$ significantly increased garlic plant height, neck diameter and leaf area index which improved by 7 , 10 and $12 \%$ over the recommended NP and by about 15,19 and $28 \%$ over the control plot respectively at 120 days. Similarly, Basic compound fertilizer applied at the rate of $400 \mathrm{~kg} \mathrm{ha}^{-1}$ improved the height and neck diameter of garlic at 120 days. Also the growth of neck diameter was significantly increased by Azofertil application at the rate of 200 $\mathrm{kg} \mathrm{ha}^{-1}$ over the rest treatments at 120 days. This rate of Azofertil fertilizer increased the growth of neck diameter by $10 \%$ and $19 \%$ over those grown using recommended NP and the control plot, respectively. Results indicate that availability of $\mathrm{Zn}$ with $\mathrm{N}, \mathrm{P}$ and $\mathrm{S}$ had significant role on the vegetative growth of garlic and the collective effect NPSZn nutrients that stimulate plant growth and thus increases leaf growths of garlic which is also in accord with the findings of Phor et al. (1995) and Alam et al. (2010). The results of Tisdale et al. (1985) are of primary importance in this regard, who reported that zinc deficiency cause shortening of the stem or stalk and stunted growth. Similarly, Khan et al. (2007) reported that significant influence of $\mathrm{N}$ and $\mathrm{Zn}$ nutrients interaction on onion plant height.
The results reported by Rizk (1997), Al-Madini et al (2000), Abdul et al. (2003), Aliyu et al. (2007) and Islam et al. (2007) concluded that increasing the application rate of NPK fertilizers increased growth parameters of onion plant. But according to the result of Mudziwa (2010) garlic plant height and neck diameter significantly increased with time of growth up to 175 days with different levels of Ammonium sulphate and Calcium nitrate and maximum at $200 \mathrm{~kg} \mathrm{ha}^{-1}$. Kale (2010) also reported the tallest onion plant height, large neck diameter and many leaves per plant due to the application of ammonium sulphate and sulphate of potash than urea and muriate of potash applied, as urea and muriate of potash containing only $\mathrm{N}$ and $\mathrm{K}$ minerals, respectively and he also revealed significantly higher number of maturity days due to ammonium sulphate and urea. In contrast to the present study Mozumder et al. (2007) obtained significant and maximum number of garlic leaves with a fertilizer combination of $175 \mathrm{~kg} \mathrm{~N}+100 \mathrm{~kg} \mathrm{~K}+24 \mathrm{~kg} \mathrm{~S} \mathrm{ha}^{-1}$ application.

Garlic shoots emergency, plant physiological maturity, and all measured garlic plant growth parameters were significantly $(P \leq 0.05)$ affected by season of crop production at all sampling growth stages except number of leaves per plant at 60 days after planting (Figures 2 and 3:A-D). However, the number of plant shoot emergency and physiological maturity prolonged during the off-season. This might be due to the effect of rain on moistening the soils before planting of the crop main-season that 


\section{Diriba-Shiferaw et al.,}

accelerate the shoots emergency, and also due to short time of optimum rainy months at the study area (mainly from mid of June to mid of September) that reduced the time of physiological maturity of the crop. But garlic plants grown in off-season by irrigation reached for physiological maturity with more days as compared with the one produced in rainy season as irrigation applied led the vegetative growth of the crop to be increased more by takingup more nutrients. Garlic plant heights were significantly increased in rainy season at 30 and 60 days; however, it was significantly increased in offseason at 90 and 120 days which might be due to availability of competing nutrients between garlic roots and leaching effect in rainy season and it indicated continues increase of plant growth. Garlic plant height linearly increased up to 90 days during off season than in rainy season (Figure 3-A). Number of leaves per plant becomes doubled as the time of growth proceeds from 30 to 120 days, but it
Sci. Technol. Arts Res. J., July-Sep 2013, 2(3): 35-50

was increased in off-season than rainy season only at 90 days after planted. The number of leaves increased significantly in off season up to 90 days, but in rainy season increased up to 120 days (Figure 3-B). However, the growth of neck diameter and LAl were significantly increased in rainy season, except they become higher in off-season at 60 and 90 days after planting, respectively (Figure 3: C, D). In addition their growths increased with greater rates up to 120 days after planting in rainy cropping season. This might be due to availability optimum moisture in both soils to take-up nutrients than the timely irrigated one. Zaman et al. (2011) also reported that garlic plant height significantly increased with growth time up to 110 days and in second year than in first year at $200 \mathrm{~kg} \mathrm{~N} \mathrm{ha}^{-1}$. Shallot plant height was significantly increased in the main rainy season of 2000 than in short rainy season of 2000 and main rainy season of 1999 (Kebede et al., 2002).

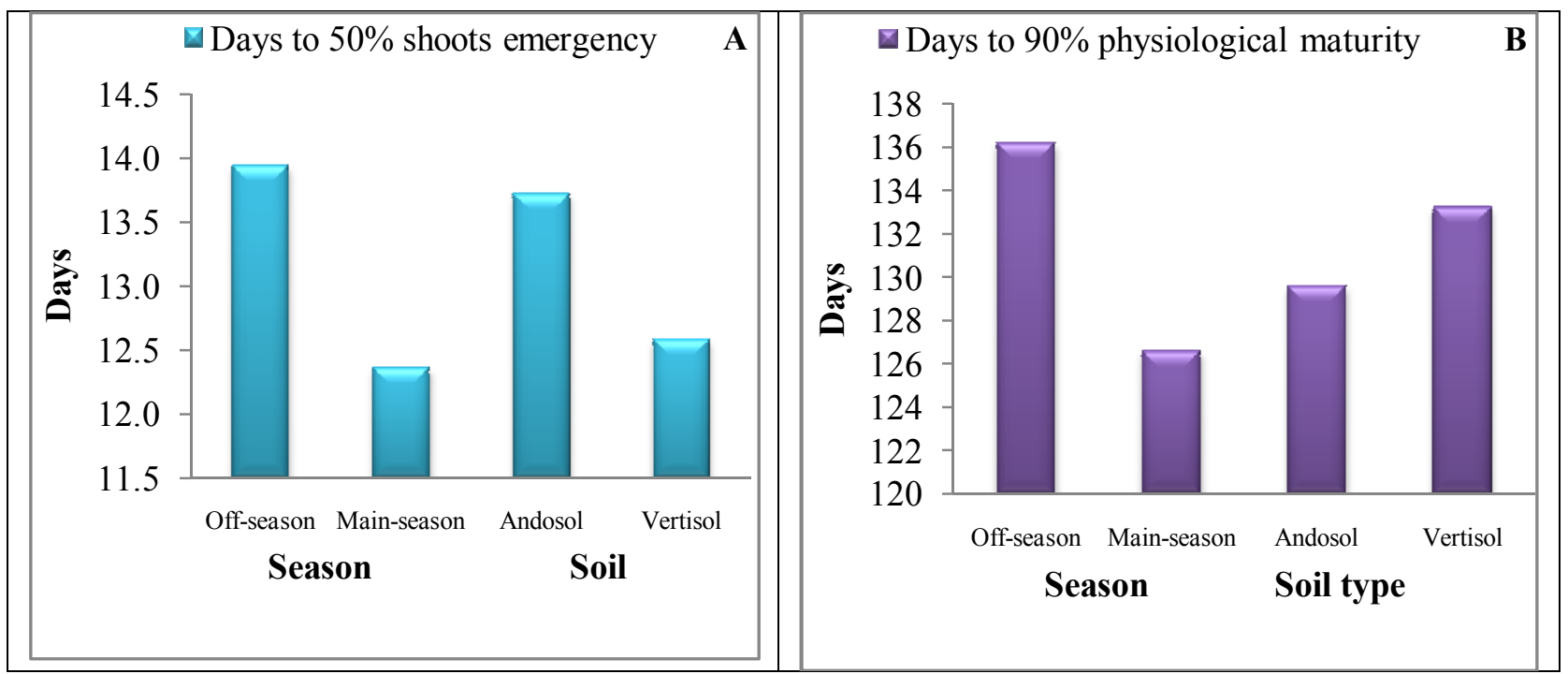

Figure 2: Days to shoots emergency (A) and physiological maturity $(B)$ of garlic plant as influenced by season (off and main seasons) and soil types (andosol and vertisol)

Soil types also significantly affected garlic shoots emergency and physiological maturity (Figure 2). Consequently, about $50 \%$ of garlic cloves were emerged earlier from vertisol and $90 \%$ of the plants were physiologically matured earlier by about 4 days on andosol. This might be due to the vertisol having a characteristic of conserving more moisture with low temperature; as availability of optimum water accelerates the germination of embryo but elongates the time of plants' physiological maturity as the foliage growth of the crop increases. According to Globerson et al. (1981) the duration of maturity was expected to be affected by different growing conditions.

Similarly, garlic plant height, neck diameter and leaf area index were significantly influenced by the soil type at all the successive growth stages of the crop (Figures 4: A, C, D). However, the number of leaves per plant produced was not significantly influenced by the soil type at all growth periods (Figure 4-B). Garlic plant height, neck diameter and LAI at 30 days were significantly increased on vertisol. This might be due to moisture conserving ability of the soil that enhances root growths of garlic as more moisture is required than nutrients at initial growth stage and this in turn improves the nutrient uptake by the crop to produce more dry matter. This leads to more growths of the plant and facilitates the production of assimilates for the growth of garlic plant at the successive growth stages. However, at 60,90 and 120 days after planting, the plant height, neck diameter and LAI growths were significantly enhanced on andosol as 


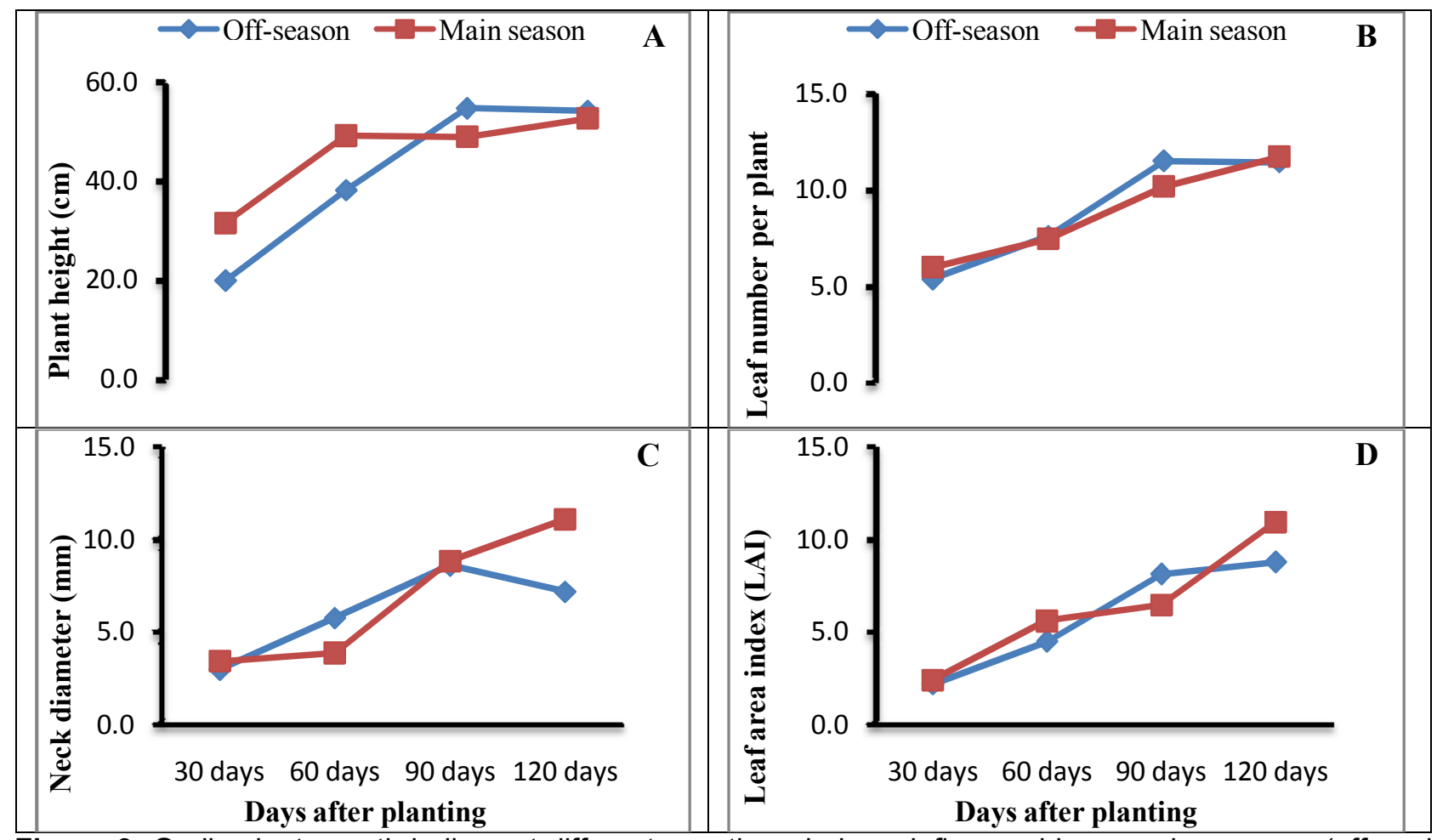

Figure 3: Garlic plant growth indices at different growth periods as influenced by cropping season (off- and main season): (A) Plant height, (B) Leaf number per plant, (C) Neck diameter, (D) Leaf area index (LAI).

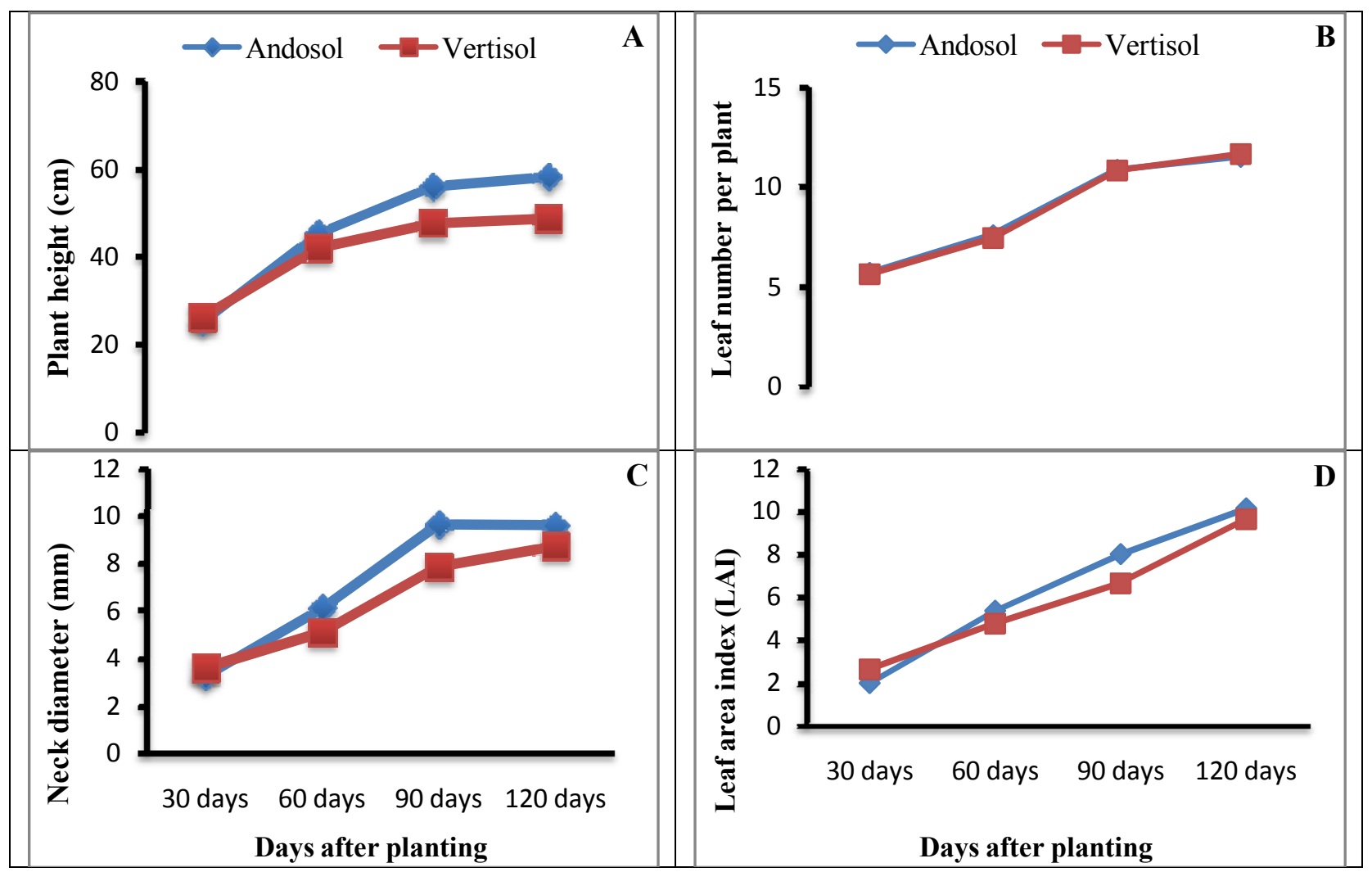

Figure 4: Garlic plant growth indices at different growth periods as affected by soil types (andosol and vertisol): (A) Plant height, (B) Leaf number per plant, (C) Neck diameter, and (D) Leaf area index (LAl) 
Diriba-Shiferaw et al.,

compared to vertisol. The availability of higher amount of nutrients in andosol helps the crop to grow more at latter growth stage due to large amount of nutrients required by the crop at pick growth stages. Application of optimum $\mathrm{N}$ with other fertilizers increases the photosynthetic rate of plant, as it increases the chlorophyll contents of plant cells which in turn increase the dry matter of the crop (Girarden et al., 1985). Increased leaf area index might be due to increased uptake of nitrogen and sulphur, which being constituent of protein; component of protoplasm and cell wall of the cell might have imparted favourable effect on the chlorophyll content of leaves. That in turn might have led to increase in synthesis of photosynthesis, which was further utilized in building up of new cells. These physiological processes might have lead to plant of better vigor, more number of leaves per
Sci. Technol. Arts Res. J., July-Sep 2013, 2(3): 35-50

plant ultimately leaf area index, and these results were also observed by Rajashekhar (1997) and Kale (2010).

\section{Effects of Fertilizers, Season and Soil on Nutrient Contents and Uptake of Garlic Plant Garlic Leaf Nutrients Content}

Table 5 illustrated the response of some nutritional values of garlic leaf tissue to the different sources and rates of compound fertilizers applied during the two successive seasons over both andosol and vertisol soil types. It is evident that, the cultivated garlic plant gained significant $(P<0.01)$ values of macro nutrients ( $N, P, K$ and $S$ ) content within leaf tissue due to the main effects of the applied compound fertilizers, season and soil; except the sulphur concentration was not significantly affected by season (Table 5 ).

Table 5: Effect of fertilizer treatments, season and soil on nutrients concentration of garlic leaf

\begin{tabular}{|c|c|c|c|c|}
\hline \multirow{2}{*}{$\begin{array}{l}\text { Fertilizer } \\
\text { treatments }\end{array}$} & \multicolumn{4}{|c|}{ Nutrient concentration (\%) } \\
\hline & $\mathbf{N}$ & $\mathbf{P}$ & $\mathrm{K}$ & $\mathbf{S}$ \\
\hline $\mathrm{C}_{0}$ & $2.04^{9}$ & $0.10^{9}$ & $1.52^{\mathrm{C}}$ & $0.22^{\dagger}$ \\
\hline $\mathrm{NP}_{92: 40}$ & $3.30^{\mathrm{bc}}$ & $0.16^{\text {et }}$ & $1.66^{\mathrm{ab}}$ & $0.36^{\mathrm{ab}}$ \\
\hline$A_{100}$ & $3.18^{\text {de }}$ & $0.16^{\text {et }}$ & $1.45^{\mathrm{c}}$ & $0.33^{\text {be }}$ \\
\hline$A_{200}$ & $3.26^{\mathrm{cd}}$ & $0.17^{\mathrm{bc}}$ & $1.48^{\mathrm{C}}$ & $0.32^{\mathrm{e}}$ \\
\hline$A_{300}$ & $3.36^{\mathrm{b}}$ & $0.19^{\mathrm{a}}$ & $1.73^{\mathrm{a}}$ & $0.36^{\mathrm{a}}$ \\
\hline $\mathrm{B}_{100}$ & $3.09^{\mathrm{et}}$ & $0.15^{\dagger}$ & $1.46^{\mathrm{c}}$ & $0.33^{\mathrm{ce}}$ \\
\hline $\mathrm{B}_{200}$ & $3.02^{\dagger}$ & $0.17^{\mathrm{ca}}$ & $1.65^{\mathrm{b}}$ & $0.33^{\text {ae }}$ \\
\hline $\mathrm{B}_{400}$ & $3.31^{\mathrm{bc}}$ & $0.19^{\mathrm{a}}$ & $1.68^{\mathrm{ab}}$ & $0.35^{\text {ad }}$ \\
\hline $\mathrm{B}_{600}$ & $3.28^{\mathrm{bc}}$ & $0.17^{\mathrm{bc}}$ & $1.69^{\mathrm{ab}}$ & $0.35^{\mathrm{ac}}$ \\
\hline $\begin{array}{l}D_{1000} \\
D_{100}\end{array}$ & $3.04^{\dagger}$ & $0.16^{\mathrm{de}}$ & $1.69^{\mathrm{ab}}$ & $0.37^{\mathrm{a}}$ \\
\hline $\begin{array}{l}D_{200} \\
D_{200}\end{array}$ & $3.24^{\mathrm{cd}}$ & $0.19^{\mathrm{a}}$ & $1.71^{\mathrm{ab}}$ & $0.37^{\mathrm{a}}$ \\
\hline $\begin{array}{l}200 \\
D_{400}\end{array}$ & $3.46^{\mathrm{a}}$ & $0.18^{\mathrm{b}}$ & $1.71^{\mathrm{ab}}$ & $0.35^{\mathrm{ac}}$ \\
\hline F-test & $* *$ & $* *$ & $* *$ & $* *$ \\
\hline \multicolumn{5}{|l|}{ Season } \\
\hline Off-season & $3.27^{\mathrm{a}}$ & $0.167^{a}$ & $1.59^{\mathrm{D}}$ & 0.33 \\
\hline Main-season & $2.99^{\mathrm{b}}$ & $0.160^{\mathrm{b}}$ & $1.66^{\mathrm{a}}$ & 0.34 \\
\hline F-test & ** & ** & ** & ns \\
\hline \multicolumn{5}{|l|}{ Soil } \\
\hline Andosol & $3.58^{\mathrm{a}}$ & $0.199^{a}$ & $2.02^{a}$ & $0.538^{a}$ \\
\hline Vertisol & $2.69^{\mathrm{b}}$ & $0.128^{\mathrm{D}}$ & $1.23^{\mathrm{b}}$ & $0.131^{\mathrm{D}}$ \\
\hline F-test & $* *$ & $* *$ & $* *$ & $* *$ \\
\hline $\mathrm{CV}(\%)$ & 3.51 & 6.57 & 5.46 & 8.55 \\
\hline
\end{tabular}

* Fertilizer treatments: $\mathrm{C}_{0}=$ control (unfertilized); $\mathrm{NP}_{92: 40}=$ recommended NP (92:40 kg ha $\left.{ }^{-1}\right) ; \mathrm{A}_{100}, \mathrm{~A}_{200}$ and $\mathrm{A}_{300}=\mathrm{Azofertl}$ at 100,200 and $300 \mathrm{~kg} \mathrm{ha}^{-1}$, respectively; $B_{100}, B_{200}, B_{400}$ and $B_{600}=$ Basic at $100,200,400$ and $600 \mathrm{~kg} \mathrm{ha}^{-1}$, respectively; $D_{100}, D_{200}$ and $D_{400}=D$-coder at 100,200 and $400 \mathrm{~kg} \mathrm{ha}^{-1}$, respectively. Means followed by the same letters within column is not significantly differed; ns $=$ indicate non-significant, and ${ }^{* *}$, indicate significant at $P<0.01$ LSD tests.

The highest $\mathrm{P}, \mathrm{K}$ and $\mathrm{S}$ concentrations were obtained from garlic fertilized with Azofertil, Basic and D-coder compound fertilizers at the rates of 300,400 and $200 \mathrm{~kg} \mathrm{ha}^{-1}$, respectively but the highest $\mathrm{N}$ concentration was obtained only due to $\mathrm{D}$ coder fertilizer application at the rate of $400 \mathrm{~kg} \mathrm{ha}^{-1}$ (Table 5). An increment of nutrients concentrations were observed due to the applications of these higher rates of compound fertilizers over the recommended fertilizers $\left(92 / 40 \mathrm{~kg} \mathrm{NP} \mathrm{ha}^{-1}\right)$, but a significant increments were seen at all the rates of the applied fertilizers as compared to the nutrients contents of garlic leaf produced on control plot. Thus, $\mathrm{N}, \mathrm{P}, \mathrm{K}$ and $\mathrm{S}$ nutrients concentrations in garlic leaves produced in response to Azofertil application at the rate of $300 \mathrm{~kg} \mathrm{ha}^{-1}$ exceeded by about $65,90,14$, and $64 \%$, and due to D-coder fertilizer application at the rate of $200 \mathrm{~kg} \mathrm{ha}^{-1}$ exceeded by about 59, 90, 13 and $68 \%$, respectively over those produced on control plot (Table 5). The lowest content of nutrients was observed in garlic leaves grown without fertilizer (control plot). These results could be explained by positive effect of compound fertilizers at higher rates 


\section{Diriba-Shiferaw et al.,}

in improving nutritional status of soils that used by garlic plants. The interaction effect of nitrogen and sulphur on $\mathrm{N}$ uptake by garlic plant was significant and the combined effect of nitrogen and sulphur on $\mathrm{N}$ or $\mathrm{S}$ uptake was found to be a synergistic effect on the production of dry matter. Nitrogen content of the crop increased significantly with the increasing levels of Azofertil and D-coder fertilizers as they supply both $\mathrm{N}$ and $\mathrm{S}$ nutrients which can interact to increase the nutrient uptake and production of dry matter. Similarly, the positive effects of $\mathrm{N}$ and $\mathrm{S}$ interaction on the uptake of sulphur by onion plant was observed at the application of $120 \mathrm{~kg} \mathrm{~N}+40 \mathrm{~kg}$ $\mathrm{S} \mathrm{ha}{ }^{-1}$ with the blanket dose of $40 \mathrm{~kg} \mathrm{P}, 75 \mathrm{~kg} \mathrm{~K}$, and $5 \mathrm{~kg} \mathrm{Zn} \mathrm{ha-1}$ plus 5 tons of cowdung ha ${ }^{-1}$ (Nasreen et al., 2007). A good supply of nitrogen stimulates root growth and development as well as the uptake of other nutrients and application of phosphorus improves the vegetables quality (Brady and Weil, 2002). Similarly, Singh (2008) got higher sulphur uptake in both onion and garlic crops with the application of $40 \mathrm{~kg} \mathrm{~S} \mathrm{ha}^{-1}$ along $80 \mathrm{~kg} \mathrm{~N}, 80 \mathrm{~kg}$ $\mathrm{P}$ and $80 \mathrm{~kg} \mathrm{~K} \mathrm{ha}^{-1}$ than NPK alone on Alfisol soil.

The production season also significantly influenced the N, P and K nutrients content of garlic leaf (Table 5). The concentrations of nitrogen and phosphorus were increased due to off-season production as compared to those produced in rainy season, but the content of potassium was higher in rainy season. This is because $\mathrm{K}$ is a mobile nutrient which needs more water to move up to leaves as it was supplied in rainy season, and higher $\mathrm{N}$ nutrient content in off-season might be due to its mobility character in rainy season that reduces the amount of them in soil by leaching by high rainfall, as it compete with garlic roots. Thus, the $\mathrm{N}$ and $\mathrm{P}$ content of garlic leaf was raised by $9 \%$ and $4.4 \%$, respectively due to off-season as compared to rainy season which might be due to higher dry matter production of garlic tissues. However, the $\mathrm{K}$ content of garlic leaf was improved by about $4.4 \%$ in rainy season over the off-season. But according to Yoldas et al. (2011) report, the content of nitrogen was decreased by its doses and $\mathrm{K}$ content were not affected during first season and did not have significant effect on $\mathrm{N}, \mathrm{P}$ and $\mathrm{K}$ amount of onion bulbs during second season by the inorganic fertilizer treatments. However, Coolong (2007) revealed that onion $\mathrm{N}$ and $\mathrm{S}$ nutrients content were lower in 2006 than during 2005 and increased with Ammonium sulphate fertility than Calcium chloride indicating that the additional supply of $\mathrm{N}$ was taken up by the plants and synergetic effect of $\mathrm{N}$ and $\mathrm{S}$ on the nutrients uptake. Fatma et al. (2012) revealed that application of $\mathrm{N}$ plus $\mathrm{P}$ fertilizers at the rates of $90+45 \mathrm{~kg} \mathrm{ha}^{-1}$ gave significantly highest values of $\mathrm{N}, \mathrm{P}$ and $\mathrm{K}$ contents in onion bulb but similar values over two seasons.
Sci. Technol. Arts Res. J., July-Sep 2013, 2(3): 35-50

The concentration of macro-nutrients analysed from garlic plant were significantly increased on andosol soil than on vertisol soil (Table 5). This might be due to the soils nutrients and organic matter contents in addition to the externally supplemented fertilizes that raised their respective nutrients content. The concentrations of $\mathrm{N}, \mathrm{P}, \mathrm{K}$ and S nutrients were improved by $33 \%, 55 \%, 64 \%$ and $311 \%$, respectively on andosol as compared to those produced on vertisol. This indicates that the soil's nutrients content is an important to optimize the fertilizers to be added for nutrients uptake and increase quality of the crop. This might be due to increased dry matter production and increased root development of garlic crop resulted in higher uptake of nutrients through availability of optimum levels of $\mathrm{N}, \mathrm{P}, \mathrm{K}$ and $\mathrm{S}$ minerals. Also according to the report of Mudziwa (2010), garlic plant tissues nitrogen and sulphur contents were significantly increased with the levels of Ammonium sulphate and Calcium nitrate fertilizers up to $200 \mathrm{~kg} \mathrm{ha}^{-1}$ regardless of the sampling date. Rosen and Tong (2001) found that significantly higher garlic shoot nitrogen content in 1996/7 than during 1995/6 cropping year at Cannon Falls location, but non significant between the years in garlic shoot at Gutches Grove location. Also the report of Bull et al. (2004) indicated that an increment of phosphorus content in garlic leaf by about $37 \%$ on sandy soil than on clayey soil.

\section{Garlic Plant Nutrients Uptake}

Response of crops to fertilizer, which is a function of nutrient uptake, is highly variable and depends on crop, type of soil, past use of the land, local weather condition as well as the choices of the whole season (FAO, 1981). The main effects of fertilizers, season and soil factors significantly $(P<0.01)$ influenced $N, P, K$ and $S$ nutrients uptake of the garlic plant; and also the one-way interactions of fertilizer and season, fertilizer and soil, and season and soil significantly influenced these macro-nutrients uptake of the crop (Tables 6 and 7). However, the two-way interaction effect of fertilizer, season and soil did not influence the uptake of plant nutrients analyzed.

Application of different compound fertilizers significantly increased the uptake of $\mathrm{N}, \mathrm{P}$ and $\mathrm{K}$ nutrients of garlic plants in off-season and that of $S$ in rainy season (Table 6). Thus, fertilization of garlic plant with D-coder compound fertilizer at the rates of 200 and $400 \mathrm{~kg} \mathrm{ha}^{-1}$ significantly increased the uptake of $\mathrm{P}, \mathrm{K}$ and $\mathrm{S}$ nutrients of the crop in both seasons, but $\mathrm{N}$ uptake significantly increased by this fertilizer rates only in the off-season. In addition, the uptake of $\mathrm{N}$ nutrient of the crop was significantly improved by the application of 
Table 6: Interaction effect of fertilizer treatments and season on nutrients uptake of garlic plant.

\begin{tabular}{|c|c|c|c|c|c|c|}
\hline \multirow{2}{*}{$\begin{array}{l}\text { Fertilizer } \\
\text { treatments }\end{array}$} & \multicolumn{3}{|l|}{ Season } & \multicolumn{3}{|l|}{ Season } \\
\hline & Off-season & Main-season & Mean $\ddagger$ & Off-season & Main-season & Mean $\ddagger$ \\
\hline & \multicolumn{3}{|c|}{$\mathrm{N}$ uptake $\left(\mathrm{kg} \mathrm{ha}^{-1}\right)$} & \multicolumn{3}{|c|}{$\mathrm{P}$ uptake $\left(\mathrm{kg} \mathrm{ha}^{-1}\right)$} \\
\hline $\mathrm{C}_{0}$ & $43.00^{k}$ & 29.14 & $36.07^{\mathrm{H}}$ & $1.24^{\prime}$ & 1.52 & $1.38^{\mathrm{G}}$ \\
\hline $\mathrm{NP}_{92: 40}$ & $82.83^{\mathrm{ab}}$ & $47.09^{\mathrm{k}}$ & $64.96^{\text {tr }}$ & $3.23^{\mathrm{ce}}$ & $2.35^{\mathrm{n}}$ & $2.79^{t}$ \\
\hline$A_{100}$ & $79.48^{\mathrm{bd}}$ & $51.55^{\mathrm{lk}}$ & $65.52^{\mathrm{V}}$ & $3.60^{\mathrm{bc}}$ & $2.81^{\mathrm{eg}}$ & $3.20^{\mathrm{V}}$ \\
\hline$A_{200}$ & $78.96^{\mathrm{bd}}$ & $56.42^{\mathrm{h \jmath}}$ & $67.69^{\mathrm{CD}}$ & $3.63^{\mathrm{ac}}$ & $3.49^{\text {bd }}$ & $3.56^{\mathrm{BC}}$ \\
\hline$A_{300}$ & $82.28^{\mathrm{ab}}$ & $63.23^{\mathrm{en}}$ & $72.76^{\mathrm{AC}}$ & $3.55^{\mathrm{bd}}$ & $3.80^{\mathrm{ab}}$ & $3.68^{A B}$ \\
\hline$B_{100}$ & $60.90^{\hbar 1}$ & $42.82^{\mathrm{k}}$ & $51.86^{\mathrm{G}}$ & $2.69^{\text {th }}$ & $2.26^{\mathrm{h}}$ & $2.48^{r}$ \\
\hline $\mathrm{B}_{200}$ & $67.44^{\mathrm{eg}}$ & $52.59^{\mathrm{Ik}}$ & $60.02^{\text {tr }}$ & $3.13^{\mathrm{dt}}$ & $3.14^{\text {de }}$ & $3.13^{\mathrm{V}}$ \\
\hline $\mathrm{B}_{400}$ & $71.74^{\mathrm{ce}}$ & $58.35^{\mathrm{gl}}$ & $65.05^{\mathrm{Lt}}$ & $3.20^{\mathrm{ce}}$ & $3.51^{\mathrm{bd}}$ & $3.36^{\mathrm{CD}}$ \\
\hline $\mathrm{B}_{600}$ & $90.21^{a}$ & $52.73^{1 \mathrm{k}}$ & $71.47^{\mathrm{BC}}$ & $3.70^{\mathrm{ab}}$ & $3.04^{\mathrm{et}}$ & $3.37^{\mathrm{CV}}$ \\
\hline$D_{100}$ & $70.23^{\mathrm{dt}}$ & $45.88^{\mathrm{k}}$ & $58.06^{\vdash}$ & $2.97^{\text {et }}$ & $2.41^{\mathrm{gn}}$ & $2.69^{\text {tr }}$ \\
\hline$D_{200}$ & $81.63^{\mathrm{ac}}$ & $65.44^{\text {en }}$ & $73.54^{\mathrm{AB}}$ & $3.71^{\mathrm{ab}}$ & $4.04^{a}$ & $3.88^{\mathrm{A}}$ \\
\hline$D_{400}$ & $90.82^{\mathrm{a}}$ & $65.19^{\text {en }}$ & $78.01^{\mathrm{A}}$ & $3.81^{\mathrm{ab}}$ & $3.75^{\mathrm{ab}}$ & $3.78^{\mathrm{AB}}$ \\
\hline \multirow[t]{3}{*}{ Mean } & $74.96^{\mathrm{A}}$ & $52.54^{\mathrm{B}}$ & & $3.20^{A}$ & $3.01^{B}$ & \\
\hline & F-test $=* *$ & $C V(\%)=13.80$ & & F-test $=* *$ & $C V(\%)=12.40$ & \\
\hline & \multicolumn{3}{|c|}{$\mathrm{K}$ uptake $\left(\mathrm{kg} \mathrm{ha}^{-1}\right)$} & \multicolumn{3}{|c|}{ S uptake $\left(\mathrm{kg} \mathrm{ha}^{-1}\right)$} \\
\hline $\mathrm{C}_{0}$ & $15.94^{\mathrm{K}}$ & $21.18^{\top}$ & $18.56^{\digamma}$ & $5.94^{m}$ & $7.00^{\mathrm{m}}$ & $6.47^{\mathrm{G}}$ \\
\hline $\mathrm{NP}_{92: 40}$ & $31.28^{\mathrm{ba}}$ & $24.61^{\dagger j}$ & $27.94^{\mathrm{Cu}}$ & $9.95^{\mathrm{j}}$ & $10.39^{\mathrm{IK}}$ & $10.17^{t}$ \\
\hline$A_{100}$ & $29.37^{\text {be }}$ & $26.23^{\mathrm{el}}$ & $27.80^{\mathrm{CL}}$ & $11.31^{\mathrm{gl}}$ & $11.49^{g 1}$ & $11.40^{\mathrm{CL}}$ \\
\hline$A_{200}$ & $30.54^{\text {be }}$ & $27.17^{\text {an }}$ & $28.86^{\mathrm{C}}$ & $11.87^{\mathrm{en}}$ & $12.96^{\mathrm{cr}}$ & $12.42^{\mathrm{b}}$ \\
\hline$A_{300}$ & $33.26^{\mathrm{ab}}$ & $29.94^{\text {be }}$ & $31.60^{\mathrm{B}}$ & $13.80^{\mathrm{bc}}$ & $14.41^{\mathrm{D}}$ & $14.10^{\mathrm{A}}$ \\
\hline$B_{100}$ & $23.69^{\text {nנ }}$ & $22.40^{\prime \prime}$ & $23.04^{\mathrm{t}}$ & $8.53^{1}$ & $9.75^{\mathrm{Kl}}$ & $9.14^{r}$ \\
\hline$B_{200}$ & $29.47^{\text {be }}$ & $29.84^{\text {be }}$ & $29.65^{\mathrm{BC}}$ & $11.00^{\mathrm{nk}}$ & $12.90^{\text {cr }}$ & $11.95^{\mathrm{BC}}$ \\
\hline $\mathrm{B}_{400}$ & $28.71^{\mathrm{cg}}$ & $29.04^{\text {bt }}$ & $28.87^{\mathrm{C}}$ & $11.09^{9 \jmath}$ & $13.03^{\mathrm{ce}}$ & $12.06^{\mathrm{BC}}$ \\
\hline $\mathrm{B}_{600}$ & $32.78^{\mathrm{ac}}$ & $26.50^{\mathrm{el}}$ & $29.64^{\mathrm{BC}}$ & $11.97^{\mathrm{en}}$ & $12.30^{\mathrm{dg}}$ & $12.14^{\mathrm{B}}$ \\
\hline$D_{100}$ & $26.56^{\mathrm{el}}$ & $24.40^{\mathrm{gJ}}$ & $25.48^{\text {Ut }}$ & $11.70^{\text {th }}$ & $10.74^{\mathrm{nk}}$ & $11.22^{\nu}$ \\
\hline$D_{200}$ & $31.86^{\mathrm{ac}}$ & $32.64^{\mathrm{ac}}$ & $32.25^{\text {AЬ }}$ & $13.51^{\mathrm{bd}}$ & $15.71^{a}$ & $14.61^{A}$ \\
\hline$D_{400}$ & $35.82^{a}$ & $33.22^{\mathrm{ab}}$ & $34.52^{A}$ & $13.98^{\mathrm{DC}}$ & $14.06^{\mathrm{bc}}$ & $14.02^{A}$ \\
\hline \multirow[t]{2}{*}{ Mean $\ddagger$} & $29.11^{A}$ & $27.26^{\mathrm{B}}$ & & $11.22^{\mathrm{B}}$ & $12.06^{\mathrm{A}}$ & \\
\hline & F-test $=^{*}$ & $C V(\%)=13.90$ & & F-test $=^{*}$ & $C V(\%)=9.60$ & \\
\hline
\end{tabular}

${ }^{*}$ Fertilizer treatments: $\mathrm{C}_{0}=$ control (unfertilized); $\mathrm{NP}_{92: 40}=$ recommended NP $\left(92: 40 \mathrm{~kg} \mathrm{ha}^{-1}\right) ; \mathrm{A}_{100}, \mathrm{~A}_{200}$ and $\mathrm{A}_{300}=\mathrm{Azofertl}$ at 100,200 and $300 \mathrm{~kg} \mathrm{ha}^{-1}$, respectively; $B_{100}, B_{200}, B_{400}$ and $B_{600}=$ Basic at 100, 200, 400 and $600 \mathrm{~kg}^{-1}$, respectively; $D_{100}, D_{200}$ and $D_{400}=D$-coder at 100,200 and $400 \mathrm{~kg} \mathrm{ha}^{-1}$, respectively. Means followed by the same letters within column is not significantly differed; ns $=$ indicate non-significant, and ${ }^{*},{ }^{* *}$, indicate significant at $P<0.05$, and $0.01 \mathrm{LSD}$ tests, respectively .

‡, The mean values due to the main effects of the applied factors are significantly different as indicated by the upper case letters.

Azofertil and Basic compound fertilizers at the rates of 300 and $600 \mathrm{~kg} \mathrm{ha}^{-1}$, respectively and by the recommended NP in the rainy season over the other treatments. Also, the $\mathrm{P}$ uptake of the crop increased by the application of Azofertil fertilizer at the rate of $300 \mathrm{~kg} \mathrm{ha}^{-1}$ in the rainy season next to D-coder fertilizer, and its lowest was obtained in garlic plants fertilized with lower rates of compound fertilizers, recommended NP and control plot in both seasons. Fertilization of the crop by D-coder fertilizer at the rate of $400 \mathrm{~kg} \mathrm{ha}^{-1}$ in off-season was improved the uptake of $\mathrm{N}$ only by $9 \%$, over the recommended NP. However, the applications of the three compound fertilizers and recommended NP in both off- and rainy seasons significantly increased the uptake of nutrients over those produced on control plot. The highest $\mathrm{P}$ uptake recorded in garlic plant fertilized with D-coder at the rates of 200 and $400 \mathrm{~kg} \mathrm{ha}^{-1}$ and
Basic at the rate of $600 \mathrm{~kg} \mathrm{ha}^{-1}$ in off-season was significantly increased over the recommended NP. However, in the rainy season, the garlic fertilized with the higher levels of the applied compound fertilizers recorded higher $P$ uptake over those produced by both the recommended NP and control plot. Consequently, the highest $\mathrm{P}$ uptake of garlic plant in response to D-coder and Azofertil application at the rates of 200 and $300 \mathrm{~kg} \mathrm{ha}^{-1}$ increased by about 62 and $72 \%$, respectively over those fertilized with the recommended NP, and by 166 and $150 \%$, respectively over the $P$ uptake of the crop produced on control plot in main season (Table $6)$.

Similarly, the application of D-coder fertilizer at the rate of $400 \mathrm{~kg} \mathrm{ha}^{-1}$ improved the uptake of $\mathrm{K}$ by about $15 \%$ over those fertilized with the 
Diriba-Shiferaw et al.,

recommended NP in off-season. However, the application of Azofertil and D-coder at the rates of 300 and $200 \mathrm{~kg} \mathrm{ha}^{-1}$, respectively increased the uptake of $\mathrm{K}$ over the other treatments in both seasons. Sulphur uptake of garlic plant was increased due to fertilization of the crop by the higher levels of the three compound fertilizers over those fertilized by the recommended fertilizers in both seasons. Consequently, the sulphur uptake of garlic in response to Azofertil and D-coder fertilization at the rates of 300 and $200 \mathrm{~kg} \mathrm{ha}^{-1}$, exceeded by 39 and $36 \%$ in off-season and by about 38 and $51 \%$ in rainy season, respectively over those fertilized with the recommended NP. However, at each treatment, a slight increase of
Sci. Technol. Arts Res. J., July-Sep 2013, 2(3): 35-50

sulphur uptake of garlic plant was observed in mainseason than the off-season. The lowest $K$ and $S$ nutrients uptake was obtained from garlic plant produced on control plot in both seasons (Table 6). Application of a combination of nutrients improved the nutrients uptake of the crop as a result of their cumulative effect on the nutrients uptake through increasing the dry matter production. Similarly, Mallingowda et al. (1995) and Girigowda et al. (2005) revealed that the highest uptake of N, P and $\mathrm{K}$ nutrients by onion when supplied with $\mathrm{N}, \mathrm{P}, \mathrm{K}$ fertilizers at the rates of $155: 22: 104 \mathrm{~kg} \mathrm{ha}^{-1}$ and 188:75:188 $\mathrm{kg} \mathrm{ha}^{-1}$ combinations, respectively over the other treatments.

Table 7: Interaction effect of fertilizer treatments and soil on nutrients uptake of garlic plant.

\begin{tabular}{|c|c|c|c|c|c|c|}
\hline \multirow{2}{*}{$\begin{array}{l}\text { Fertilizer } \\
\text { Treatments* }\end{array}$} & \multicolumn{3}{|l|}{ Soil } & \multicolumn{3}{|l|}{ Soil } \\
\hline & Andosol & Vertisol & Mean $\ddagger$ & Andosol & Vertiso & Mean $\ddagger$ \\
\hline & \multicolumn{3}{|c|}{$\mathbf{N}$ uptake $\left(\mathrm{kg} \mathrm{ha}^{-1}\right)$} & \multicolumn{3}{|c|}{ P uptake $\left(\mathrm{kg} \mathrm{ha}^{-1}\right)$} \\
\hline $\mathrm{C}_{0}$ & $44.88^{n}$ & $27.26^{\prime}$ & $36.07^{\mathrm{H}}$ & $1.68^{\mathrm{K}}$ & 1.08 & $1.38^{\mathrm{G}}$ \\
\hline $\mathrm{NP}_{92: 40}$ & $69.18^{\mathrm{ca}}$ & $60.74^{\mathrm{de}}$ & $64.96^{\text {tr }}$ & $3.05^{\mathrm{eg}}$ & $2.54^{\mathrm{nI}}$ & $2.79^{5}$ \\
\hline $\mathrm{A}_{100}$ & $77.06^{\mathrm{bc}}$ & $53.97^{\mathrm{en}}$ & $65.52^{\mathrm{L}}$ & $3.88^{a}$ & $2.53^{\mathrm{nl}}$ & $3.20^{\mathrm{L}}$ \\
\hline$A_{200}$ & $77.77^{\mathrm{ac}}$ & $57.61^{\mathrm{et}}$ & $67.69^{\mathrm{CD}}$ & $4.43^{\mathrm{bc}}$ & $2.69^{\text {th }}$ & $3.56^{\mathrm{BC}}$ \\
\hline$A_{300}$ & $73.07^{\mathrm{bc}}$ & $72.44^{\mathrm{bc}}$ & $72.76^{\mathrm{AC}}$ & $4.27^{\mathrm{bd}}$ & $3.08^{\mathrm{et}}$ & $3.68^{A B}$ \\
\hline$B_{100}$ & $58.86^{\mathrm{et}}$ & $44.86^{\mathrm{h}}$ & $51.86^{\mathrm{G}}$ & $3.22^{\mathrm{e}}$ & $1.73^{k}$ & $2.48^{\vdash}$ \\
\hline$B_{200}$ & $69.65^{\mathrm{cd}}$ & $50.39^{\text {th }}$ & $60.02^{\text {tr }}$ & $4.07^{\mathrm{cd}}$ & $2.20^{\prime \prime}$ & $3.13^{\mathrm{V}}$ \\
\hline $\mathrm{B}_{400}$ & $71.05^{\mathrm{bc}}$ & $59.04^{\mathrm{et}}$ & $65.05^{\text {Ut }}$ & $4.08^{\mathrm{cd}}$ & $2.63^{g !}$ & $3.36^{\mathrm{CD}}$ \\
\hline $\mathrm{B}_{600}$ & $87.15^{\mathrm{a}}$ & $55.79^{\mathrm{eg}}$ & $71.47^{\mathrm{BC}}$ & $4.21^{\mathrm{bd}}$ & $2.53^{\mathrm{hi}}$ & $3.37^{\mathrm{CV}}$ \\
\hline$D_{100}$ & $69.63^{\mathrm{cd}}$ & $46.48^{g h}$ & $58.06^{\vdash}$ & $3.42^{\mathrm{e}}$ & $1.96^{\mathrm{k}}$ & $2.69^{\text {tr }}$ \\
\hline$D_{200}$ & $87.46^{a}$ & $59.61^{\mathrm{dt}}$ & $73.54^{\mathrm{AB}}$ & $5.07^{\mathrm{a}}$ & $2.68^{\mathrm{eh}}$ & $3.88^{\mathrm{A}}$ \\
\hline$D_{400}$ & $79.82^{\mathrm{ab}}$ & $76.19^{\mathrm{bc}}$ & $78.01^{A}$ & $4.56^{\mathrm{D}}$ & $3.00^{\mathrm{eg}}$ & $3.78^{\mathrm{AB}}$ \\
\hline \multirow[t]{3}{*}{ Mean } & $72.13^{A}$ & $55.37^{\mathrm{B}}$ & & $3.83^{A}$ & $2.39^{B}$ & \\
\hline & F-test $=* *$ & $C V(\%)=1$ & & F-test $=^{* *}$ & $C V(\%)=$ & \\
\hline & \multicolumn{3}{|c|}{$\mathrm{K}$ uptake $\left(\mathrm{kg} \mathrm{ha}^{-1}\right)$} & \multicolumn{3}{|c|}{ S uptake $\left(\mathrm{kg} \mathrm{ha}^{-1}\right)$} \\
\hline $\mathrm{C}_{0}$ & $25.37^{\text {th }}$ & $11.75^{\top}$ & $18.56^{F}$ & $8.93^{\mathrm{et}}$ & $4.01^{k}$ & $6.47^{\mathrm{G}}$ \\
\hline $\mathrm{NP}_{92: 40}$ & $30.53^{\mathrm{de}}$ & $25.36^{\text {th }}$ & $27.94^{\mathrm{CD}}$ & $12.73^{\mathrm{d}}$ & $7.60^{91}$ & $10.17^{\mathrm{t}}$ \\
\hline $\mathrm{A}_{100}$ & $35.77^{\mathrm{bc}}$ & $19.83^{\prime \prime}$ & $27.80^{\mathrm{CD}}$ & $16.46^{\mathrm{C}}$ & $6.34^{\prime \prime}$ & $11.40^{\mathrm{CU}}$ \\
\hline$A_{200}$ & $35.75^{\mathrm{bc}}$ & $21.96^{\text {nj }}$ & $28.86^{\mathrm{C}}$ & $17.57^{\mathrm{C}}$ & $7.27^{\mathrm{nI}}$ & $12.42^{\mathrm{B}}$ \\
\hline$A_{300}$ & $35.46^{\mathrm{bc}}$ & $27.73^{\mathrm{eg}}$ & $31.60^{\mathrm{B}}$ & $18.99^{\mathrm{b}}$ & $9.22^{\mathrm{e}}$ & $14.10^{\mathrm{A}}$ \\
\hline $\mathrm{B}_{100}$ & $30.86^{\mathrm{de}}$ & $15.23^{\mathrm{Kl}}$ & $23.04^{\mathrm{t}}$ & $13.07^{a}$ & $5.21^{\mathrm{jk}}$ & $9.14^{r}$ \\
\hline $\mathrm{B}_{200}$ & $38.80^{\mathrm{ab}}$ & $20.51^{1 J}$ & $29.65^{\mathrm{BC}}$ & $16.40^{\mathrm{C}}$ & $7.49^{9 \prime}$ & $11.95^{\mathrm{BC}}$ \\
\hline $\mathrm{B}_{400}$ & $34.18^{\mathrm{cd}}$ & $23.57^{\mathrm{gl}}$ & $28.87^{\mathrm{C}}$ & $17.33^{\mathrm{C}}$ & $6.80^{\mathrm{nl}}$ & $12.06^{\mathrm{BC}}$ \\
\hline $\mathrm{B}_{600}$ & $36.65^{\mathrm{ac}}$ & $22.64^{\mathrm{hl}}$ & $29.64^{\mathrm{BC}}$ & $17.63^{\mathrm{C}}$ & $6.65^{\mathrm{hi}}$ & $12.14^{\mathrm{B}}$ \\
\hline$D_{100}$ & $32.95^{\mathrm{cd}}$ & $18.02^{\mathrm{jk}}$ & $25.48^{\text {Ut }}$ & $17.24^{\mathrm{C}}$ & $5.21^{\mathrm{Jk}}$ & $11.22^{\mathrm{U}}$ \\
\hline$D_{200}$ & $40.68^{a}$ & $23.82^{\pi 1}$ & $32.25^{\mathrm{AB}}$ & $21.45^{\mathrm{a}}$ & $7.76^{\text {th }}$ & $14.61^{\mathrm{A}}$ \\
\hline$D_{400}$ & $40.95^{a}$ & $28.09^{\mathrm{et}}$ & $34.52^{A}$ & $19.48^{\mathrm{D}}$ & $8.57^{\mathrm{eg}}$ & $14.02^{\mathrm{A}}$ \\
\hline \multirow[t]{2}{*}{ Mean $\ddagger$} & $34.83^{A}$ & $21.54^{B}$ & & $16.44^{A}$ & $6.84^{B}$ & \\
\hline & F-test $=* *$ & $C V(\%)=1$ & & F-test $={ }^{* *}$ & $C V(\%)=$ & \\
\hline
\end{tabular}

* Fertilizer treatments: $\mathrm{C}_{0}=$ control (unfertilized); $\mathrm{NP}_{92: 40}=$ recommended NP $\left(92: 40 \mathrm{~kg} \mathrm{ha}^{-1}\right) ; \mathrm{A}_{100}, \mathrm{~A}_{200}$ and $\mathrm{A}_{300}=\mathrm{Azofertl}$ at 100, 200 and $300 \mathrm{~kg} \mathrm{ha}^{-1}$, respectively; $B_{100}, B_{200}, B_{400}$ and $B_{600}=$ Basic at $100,200,400$ and $600 \mathrm{~kg} \mathrm{ha}^{-1}$, respectively; $D_{100}, D_{200}$ and $D_{400}=D$-coder at 100,200 and $400 \mathrm{~kg} \mathrm{ha}^{-1}$, respectively. Means followed by the same letters within column is not significantly differed; ns = indicate non-significant, and ${ }^{*},{ }^{* *}$, indicate significant at $P<0.05$, and 0.01 LSD tests, respectively

$\ddagger$,The mean values obtained due to the main effects of the applied factors are significantly different as indicated by uppercase letters.

These highest uptake of nutrients of the crop obtained might be due to the applications of $N, P, S$ and $\mathrm{Zn}$ nutrients by $\mathrm{D}$-coder, and $\mathrm{N}$ and $\mathrm{S}$ nutrients by Azofertil compound fertilizers; as nitrogen improve the vegetative growth and accelerating the photosynthates in storage organs of the crop resulting in an increased diameter and weight of the bulb (Sharma, 1992); and as root growth, 


\section{Diriba-Shiferaw et al.,}

particularly development of lateral roots and fibrous rootlets which responsible for nutrients uptake from the soil is positively encouraged by phosphorus (Barker and Pilbeam, 2007). Also due an important role of sulphur in plant protein and some hormones formation, necessary for enzymatic action, chlorophyll formation, synthesis of certain amino acids and vitamins, hence it helps have a good vegetative growth leading to get high yield (Tisdale and Nelson, 1985; El-Shafie and El-Gamaily, 2002). Also it is attributed to the positive effect of sulphur on nitrogen absorption and on increasing potassium uptake with the greater dry matter production, and these are also reported by El-Bassiony (2006) and Singh et al. (1996) on onion. Zinc is also essential for plant growth, activates many enzymatic reactions and is necessary for chlorophyll synthesis and carbohydrate formation (Vitosh et al., 1994). Similarly, Abdulsalam and Hamaiel (2004) reported significantly increased mineral N, P and K contents of onion with the application of compound fertilizer containing $14 \% \mathrm{~N}, 38 \% \mathrm{P}$ and $10 \% \mathrm{~K}$ nutrients.

The uptake of macro-nutrients analysed from garlic plants were significantly increased on andosol soil than that of vertisol soil (Table 7). The N, P, K and $S$ nutrients uptake by garlic plant was improved by $30,60,62$ and $140 \%$, respectively on andosol as compared to those produced on vertisol. This might be due to the increased nutrients content and dry matter production of the plant by the cumulative effect of nutrients available in andosol in addition to the externally supplemented fertilizes that raised their respective nutrients uptake. The interaction of fertilizers and soil types significantly improved the nutrients uptake of the crop, but of all the fertilizer treatments the application of D-coder compound fertilizer at the rate of $200 \mathrm{~kg} \mathrm{ha}^{-1}$ on andosol significantly improved the uptake of $\mathrm{N}, \mathrm{P}, \mathrm{K}$ and $\mathrm{S}$ nutrients of garlic plant, and their lowest uptake was recorded from plants grown on control plots of vertisol (Table 7). The results indicate that soil having low amount of nutrients required higher levels of compound fertilizer to substitute the recommended NP level. This might be due to the increased dry matter production and increased root
Sci. Technol. Arts Res. J., July-Sep 2013, 2(3): 35-50

development of garlic crop resulted in higher uptake of phosphorus through availability of optimum levels of N, P, K and S minerals. Kumar and Rao (1992) and Panda et al. (1995) indicated that increasing $N$ and $P$ uptake with increasing $N$ and $P$ fertilizer applications to the soil as a result of improved availability and uptake through increased root growth and effective absorption. Similarly Nasreen and Hossain (2004) found the highest N, P, K and S uptake during all growth stages of onion on Grey Terrace Soil from the application of fertilizer combination of $100 \mathrm{~kg} \mathrm{~N}, 44 \mathrm{~kg} \mathrm{P}, 83 \mathrm{~kg} \mathrm{~K}, 20 \mathrm{~kg} \mathrm{~S}$ and $5 \mathrm{~kg} \mathrm{Zn} \mathrm{ha}^{-1}$ which is in concise with the results obtained on andosol supplemented with D-coder fertilizer. Also according to the report of Kale (2010) significantly greatest $\mathrm{N}, \mathrm{P}$ and $\mathrm{K}$ uptake of onion was due to Ammonium sulphate and sulphate of potash application than urea, sheep manure, farm yard manure and muriate of potash. It is attributed to the positive effect of sulphur on nitrogen absorption with the greater dry matter production with the supply of nutrients especially $K$ and $S$. Increases in K content with increased level of sulphur were also reported by El-Bassiony (2006). Also the present results are in close conformity with the findings of Singh et al. (1996), FAl (1999) and Desuki et al. (2006).

Also the nutrients uptake of garlic plant were significantly influenced by the interaction of soil type and season of crop production, and the highest uptake of $\mathrm{N}, \mathrm{P}, \mathrm{K}$ and $\mathrm{S}$ nutrients were recorded in plants produced on andosol in off-season (Table 8). The lowest $P, K$ and $S$ nutrients uptake were obtained in plants produced on vertisol in offseason. However, the lowest $\mathrm{N}$ uptake of garlic was obtained on andosol in main rainy season. The highest $\mathrm{N}, \mathrm{P}, \mathrm{K}$ and $\mathrm{S}$ uptake due to the crop grown on andosol in off-season was improved by about $100,125,84$ and $311 \%$, respectively over their respective lowest nutrients uptake of the crop. This indicates that garlic production during off-season by irrigation over the soil having more nutrients in addition to the externally supplemented fertilizers led to the production of more dry matter which in turn enhances the uptake of nutrients from the soil.

Table 8: Interaction effect of season and soil on nutrients uptake $\left(\mathrm{kg} \mathrm{ha}^{-1}\right)$ by garlic plant.

\begin{tabular}{|c|c|c|c|c|c|}
\hline Season & Soil & $\begin{array}{l}\text { N uptake } \\
\left(\text { kg ha }^{-1}\right)\end{array}$ & $\begin{array}{l}\text { P uptake } \\
\left(\mathrm{kg} \mathrm{ha}^{-1}\right)\end{array}$ & $\begin{array}{l}\text { K uptake } \\
\left(\mathrm{kg} \mathrm{ha}^{-1}\right)\end{array}$ & $\begin{array}{l}\text { S uptake } \\
\left(\mathrm{kg} \mathrm{ha}^{-1}\right)\end{array}$ \\
\hline \multirow[b]{2}{*}{ Off-season } & Andosol & $96.20^{a}$ & $4.44^{\mathrm{a}}$ & $37.73^{\mathrm{a}}$ & $18.05^{\mathrm{a}}$ \\
\hline & Vertisol & $53.72^{\mathrm{b}}$ & $1.97^{\mathrm{a}}$ & $20.49^{a}$ & $4.39^{a}$ \\
\hline \multirow{2}{*}{ Main-season } & Andosol & $48.06^{C}$ & $3.21^{D}$ & $31.93^{\mathrm{D}}$ & $14.82^{\mathrm{D}}$ \\
\hline & Vertisol & $57.02^{\mathrm{b}}$ & $2.81^{c}$ & $22.59^{c}$ & $9.30^{\mathrm{C}}$ \\
\hline LSD & & ** & ** & ** & ** \\
\hline CV (\%) & & 13.80 & 12.40 & 13.90 & 9.60 \\
\hline
\end{tabular}




\section{CONCLUSIONS}

The morphological characters like plant height, neck diameter and leaf area index, and the concentrations of $\mathrm{N}, \mathrm{P}, \mathrm{K}$ and $\mathrm{S}$ nutrients, and their uptake by garlic plant were significantly influenced by the applications of different compound fertilizers, season and soil types at different growth stages. Majority of garlic growth indices showed linearly significant increase with growth periods in main rainy season than in off-season. Garlic plant shoots emergency was earlier on vertisol but physiological maturity was earlier on andosol, however, both of them were earlier in rainy season. With respect to the applications of different compound fertilizers at various rates, the days to plant germination and physiological maturity, and number of leaves per plant at all growth stages were not significantly affected.

In conclusion, garlic plants showed differential response to different rates of compound fertilizers, cropping season and soil types. Significantly superior response of garlic, as observed by the vegetative growth, nutrients content and uptake of the crop, was obtained when garlic planted in offseason by irrigation over andosol with the fertilizations of D-coder fertilizer at the rate of $200 \mathrm{~kg}$ $\mathrm{ha}^{-1}(28 \% \mathrm{~N}+18 \% \mathrm{P}+42 \% \mathrm{~S}+0.2 \% \mathrm{Zn})$ followed by Azofertil fertilizer at the rate of $300 \mathrm{~kg} \mathrm{ha}^{-1}(90 \%$ $\mathrm{N}+75 \% \mathrm{~S}$ ). But, Basic fertilizer responded to higher growths and nutrient uptake of nutrients at higher levels $\left(400\right.$ and $\left.600 \mathrm{~kg} \mathrm{ha}^{-1}\right)(36 \% \mathrm{~N}+24 \% \mathrm{P}+88 \%$ $\mathrm{K}+40 \% \mathrm{CaO}$ and $54 \% \mathrm{~N}+36 \% \mathrm{P}+132 \% \mathrm{~K}+$ $60 \% \mathrm{CaO}$ ) than the other treatments. This led to conclude that Azofertil and D-coder fertilizers at the rates of 200 and $300 \mathrm{~kg} \mathrm{ha}^{-1}$, respectively are better to substitute the locally recommended NP fertilizers for garlic production on the soils of the area under the dry conditions by irrigation. However, further research should be under taken by comparing or supplementing with different sources of organic manures to minimize the fertilizers cost and to increase the productivity of heavy nutrient feeder garlic plant, as applications of higher doses of these compound fertilizers become unaffordable especially for poor farmers of the country.

\section{ACKNOWLEDGEMENTS}

The authors express their appreciation to the Ethiopian Ministry of Education for funding the research work and Haramaya University for facilitating the budget. We also acknowledge the staff, laboratory technicians and field assistants at the Debre Zeit Agricultural Research Centre of Ethiopia for their logistic supports and technical help during conducting the field experiment and laboratory activities of the study.

\section{REFERENCES}

Abdul, G., Muhammad, S.J., Ghulam, K., Kashif, W. (2003). Effect of different NPK levels on the growth and yield of three onion (Allium cepa L.) varieties. Asian Journal of Plant Sciences 2: 342-346.

Abdulsalam, M.A.A.L., Hamaiel, A.F. (2004). Effect of planting dates and compound fertilizers on growth, yield and quality of hassawi onion under Al-Hassa Oasis conditions. Scientific Journal of King Faisal University (Basic and Applied Sciences). 5(1): 65-79.

Alam, M.N., Abedin, M.J., Azad, M.A.K. (2010). Effect of micronutrients on growth and yield of onion under calcareous soil environment. International Research Journal of Plant Science 1(3): 056-061.

Aliyu, U., Magaji, M.D., Singh, A., Mohammed, S.G. (2007). Growth and yield of onion (Allium cepa L.) as influenced by nitrogen and phosphorus levels. International Journal of Agricultural Research 2: 937944.

Al-Madini, A.M., Al-Thabt, S.S., Hamail, A.F. (2000). Effects of different application rates of two compound fertilizers on growth, yield and yield mineral composition of onion (Allium Cepa L.). Egyptian Journal of Applied Science 15(10).

Amin, M.R., Hasan, M.K., Naher, Q., Hossain, M.A., Noor, Z.U. (2007). Response of Onion to NPKS Fertilizers in Low Ganges River Flood Plain Soil. International Journal of Sustainable Crop Production 2(1): 11-14.

Barker, A.V., Pilbeam, D.J. (2007). Handbook of Plant Nutrition. Taylor and Francis, Boca Raton London New York, Pp 21-183.

Bashour, I.I. (2001). Fertility and Fertilizer Requirements. In Rural Integrated Development of the Mountains of Northern Lebanon. FAO Report to Ministry of Agriculture, Beirut, Lebanon. Pp 116.

Brady, N.C., Weil, R.R. (2002). The nature and properties of soils. Thirteenth edition. Pearson Education Asia. Delhi, India. Pp.960.

Brewster, J.L., Butler, H.A. (1989). Effects of nitrogen supply on bulb development in onions (Allium cepa L.). Journal of Experimental Botany 40: 1155-1162.

Bull, L.T., Costa, M.C.G., Novello, A., Fernandes, D.M., Boas, R.L.V. (2004). Doses and Forms of Application of Phosphorus in Vernalized Garlic. Scientia Agricola (Piracicaba, Braz.) 61(5):516-521.

Central Statistical Agency (CSA). (2011). Statistical Report on Area and Production of Crops, and Farm Management Practices. Ethiopian Agricultural Sample Survey, (2010/2011). Federal Democratic Republic of Ethiopia, Central Statistical Authority, Addis Ababa. Statistical Bulletin 505, Volume VIII. Pp 13-20.

Chapman, H.D., Pratt, P.F. (1982). Methods of Plant Analysis, I. Methods of Analysis for Soil, Plant and Water. Chapman Publishers, Riverside, California, USA.

Coolong, T.W. (2007). Physiological factors affecting onion (Allium Cepa L.) storability-cultural methods for 
Diriba-Shiferaw et al.,

improving postharvest quality. A Dissertation Submitted to the Graduate Faculty of the University of Georgia, Athens, Georgia, Pp. 56.

Cottenie, A., Verloo, M., Kickens, L., Velghe, G., Camerlynck, R. (1982). Chemical analysis of plants and soils. Laboratory of Analytical and Agrochemistry. State University, Ghent Belgium, Pp.63.

Desuki, M.M., Abdel-Mouty, Ali, A.H. (2006). Response of onion plants to additional dose of potassium application. Journal of Applied Sciences Research 2(9): 592-597.

El-Bassiony, A.M. (2006). Effect of potassium fertilization on growth, yield and quality of onion plants. Journal of Applied Sciences and Research 2(10): 780-785.

El-Shafie, F.S., El-Gamaily, E. (2002). Effect of organic manure, sulphur and microelements on growth, bulb yield, storability and chemical composition of onion plants. Minufiya Journal of Agricultural Research. 27(2): 407-424.

FAl. (1999). Fertilizer Statistics 1997-98. Fertilizer Association of India, New Delhi, pp 319-332: In D.K. Benbi, M.S. Brar and S.K. Bansal, 2006. Proceedings of the International Symposium held at Punjab Agricultural University, Ludhiana, India, 22-25 November 2006. Volume I: Balanced Fertilization for Sustaining Crop Productivity.

Faten, S., Shaheen, A.El-Al, Fatma, A.M., Rizk, A., Hafez, M.M. (2010). Influence of irrigation intervals and potassium fertilization on productivity and quality of onion plant. International Journal of Academic Research 2: 110-116.

Fatma, A.R., Shaheen, A.M., El-Samad, E.H. Abd, Sawan, O.M. (2012). Effect of Different Nitrogen Plus Phosphorus and Sulphur Fertilizer Levels on Growth, Yield and Quality of Onion (Allium cepa L.). Journal of Applied Sciences Research.8(7): 3353-3361.

Food and Agricultural Organization (FAO). (2003). Global review of area and production of garlic, 135-139.

Getachew, T., Asfaw, Z. (2000). Achievements in shallot and garlic research report. No.36. Ethiopian Agricultural Research Organization, Addis Ababa. Ethiopia.

Girarden, P., Tollenaar, M., Muldoon, J.F. (1985). "Photosynthetic Rate and Chlorophyll Content". Canadian Journal of Plant Science 65: 491-500.

Girigowda, J.R., Narsegowda, N.C., Krishna, H.C. (2005). Effect of fertilization levels on uptake of primary nutrients and yield of onion hybrids. Mysore Journal of Agricultural Sciences 39(4): 557-560.

Globerson, D., Sharir, A., Eliasi, R. (1981). The nature of flowering and seed maturation of onions as a basis for mechanical harvesting of the seeds, Acta Horticulture 111:99-108.

Gubb, I.R., Tavis, M.S.H. (2002). Onion preharvest and postharvest considerations. Pp. 237-250. In: H.D. Rabinowitch, and L. Currah (eds.). Allim Crop science. CABI publishing, UK.
Sci. Technol. Arts Res. J., July-Sep 2013, 2(3): 35-50

Havlin, J.L., Beaton, J.D., Tisdale, S.L., Nelson, W.L. (2007). An introduction to nutrient management. Soil Fertility and Fertilizers. Pp. 244-289.

Hazelton, P., Murphy, B. (2007). Interpreting Soil Test Results: What do all the numbers mean? CSIRO Publishing. $2^{\text {nd }}$ ed. Australia. Pp. 59-90.

Islam, M.K., Alam, M.F., Islam, A.K.M.R. (2007). Growth and Yield Response of Onion (Allium Cepa L.) Genotypes to Different Levels of Fertilizers. Bangladesh Journal of Botany 36(1): 33-38.

Jackson, M.L. (1967). Soil Chemical Analysis. Prentice Hall, New York, USA.

Kakara, A., Abdullahzai, M.K., Saleem, M., Shah, S.A.Q. (2002). Effect of nitrogenous fertilizer on growth and yield of garlic. Asian Journal of Plant Sciences 1(5): 544-545.

Kale, L. (2010). Studies on Effect of Different Sources of Nitrogen and Potassium on Productivity and Shelf Life of Onion (Allium Cepa L.) Var. Arka Kalyan. Msc Thesis Submitted to the University of Agricultural Sciences, Dharwad. Pp 28-69.

Kebede Woldetsadik, Ulla Gertsson, Johan Ascard. (2002). Season, and Nitrogen Source and Rate Affect Development and Yield of Shallot. Journal of Vegetable Crop Production 8(1): 71-81.

Khan, A.A., Muhammad, Z., Abdul, B., Fazal, M. (2007). Response of Onion (Allium Cepa) Growth and Yield to Different Levels of Nitrogen and Zinc in Swat Valley. Sarhad Journal of Agriculture. 23(4):933-936.

Kumar, K., Rao, K.V.P. (1992). Nitrogen and phosphorus requirement of upland rice in Manipur. Indian Journal of Agronomy 29:306-349.

Landon, J.R. (1991). Booker tropical soil manual: A Handbook for Soil Survey and Agricultural Land Evaluation in the Tropics and Subtropics. Longman Scientific and Technical, Essex, New York. 474p.

Luo, C., Branlard, G., Griffin, W.B., MCNEil, D.L. (2000). The effect of nitrogen and sulphur fertilization and their interaction with genotype on wheat glutamines and quality parameters. Journal of Cereal Science 31:185194.

Mahmood, N. (2000). Horticultural crops production. p459.

Mallingowda, B., Sulikeri, G.S., Hulamani, N.C., Murthy, B.G., Mudalgeri, B.B. (1995). Effect of NPK and FYM on growth parameters of onion, garlic and coriander. Current Research 24(11): 212-213.

Maly, I., Bartos, J., Hlusek, J., Kopec, K., Peteikova, K., Rod, J., Spitz, P. (1998). Polni zelina_stvi. Agrospoj Praha, 175-185.

Mattew, L.A., Wedell, A.N., Willium, D.P., John, H.P. (2000). Micronutrient status. Agronomic Journal 92: 261-268.

Mozumder, S.N., Moniruzzaman, M., Halim, G.M.A. (2007). Effect of $N, K$ and $S$ on the Yield and Storability of Transplanted Onion (Allium cepa L.) in the Hilly Region. Journal of Agriculture and Rural Development 5(1\&2): 58-63. 


\section{Diriba-Shiferaw et al.,}

Mudziwa, N. (2010). Yield and Quality Responses of Egyptian White Garlic (Allium sativum L.) and Wild Garlic (Tulbaghia violacea Harv.) to Nitrogen Nutrition. PhD Thesis, University of Pretoria, South Africa. Pp. 31-76.

Murashkina, M., Southard R.J., Pettygrove, G.S. (2006). Potassium Fixation in Silt, Sand and Clay Fractions of Soils Derived from Granitic Alluvium of the San Joaquin Valley, California. The $18^{\text {th }}$ World Congress of Soil Science (July 9-15, 2006) at Philadelphia, Pennsylvania, USA.

Nasreen, S., Hossain, A.K.M. (2004). Nutrient Uptake and Yield of Onion as Influenced by Chemical Fertilizer and Organic Manure. Indian Journal Agricultural Research 38(3): 164 - 170.

Nasreen, S., Haque, M.M., Hossain, M.A. and Farid, A.T.M. 2007. Nutrient Uptake and Yield of Onion as Influenced by Nitrogen and Sulphur Fertilization. Bangladesh Journal of Agriculture Research 32(3): 413-420.

Nonnecke, I.L. (1989). Vegetable Production, New York. $657 p$.

Nori, M., Bayat, F., Esmaeili, A. (2012). Changes of vegetative growth indices and yield of garlic (Allium sativum L.) in different sources and levels of nitrogen fertilizer. International Journal of Agricultural Crop Sciences 4(18): 1394-1400.

Olsen, S.R., Cole, C.V., Watanabe, F.S., Dean, L.A. (1954). Estimation of available phosphorus in soils by extraction with sodium bicarbonate. Circ. U.S. Dep. Agric. 939

Panda, S.C., Panda, P.C.P., Nanda, S.S. (1995). Nitrogen and phosphorus uptake from Tithonia diversifolia and inorganic fertilizers and their effect on maize yield in Malawi. 264-266 p. Proceeding of Symposium on maize production technology for the future. Challenge and opportunities in Africa A.A., Ethiopia 21-25 September 1998. CIMMYT and EARO.

Phor, S.K., Pandey, U.C., Verma, U. (1995). Effects of zinc on the growth and yield of garlic (Allium sativum L). Crop Research Hisar 9(2): 286-291.

Potgieter, J. (2006). Verbal communication on macroelements application time. Researcher, Limpopo Department of Agriculture. April 2006.

Rajashekhar, A.A. (1997). Studies on the effect of nitrogen and phosphorus on growth, yield and quality of onion (Allium cepa L.) cv. Telgi Red. M.Sc. thesis, Univ. Agric. Sci., Dharwad, Karnataka (India).

Rizk, F.A. (1997). Productivity of onion plant (Allium Cepa, L.) as affected by method of planting and NPK application. Egyptian Journal of Horticulture 24(2): 219-238.

Rosen, C. J., Tong, C.B.S. (2001). Yield, Dry Matter Partitioning, and Storage Quality of Hardneck Garlic as
Sci. Technol. Arts Res. J., July-Sep 2013, 2(3): 35-50

Affected by Soil Amendments and Scape Removal. Hortscience 36(7):1235-1239.

Ryan, J. (2008). A Perspective on balanced fertilization in the Mediterranean Region. The Turkish Journal of Agriculture and Forestry 32: 79-89.

Salomon, R. (2002). Virus diseases in garlic and the propagation of virus free planting. Pp. 311-327. In: Rabinwitch, H.D. and L. Currah (Eds.). Allium crop sciences: Recent advances. CAB International, Wallingford, UK.

Singh, H., Singh, S., Singh, V. (1996). Response of onion (Allium cepa L.) to nitrogen and sulphur. Annals of Agricultural Research 17(4): 441-444.

Singh, R.B., Singh, S.B. (1999). Effect of nitrogen, phosphorus and potassium on growth and yield of rainy season onion (Allium cepa L.) raised from seedling. Vegetable Science 26:93-94.

Singh, S. (2008). Effect of Sulphur on Yields and S Uptake by Onion and Garlic Grown in Acid Alfisol of Ranchi. Agricultural Science and Digest, 28(3): 189 191.

Snedecor, G.W., Cochran, W.G. (1980). Statistical Methods. $12^{\text {th }}$ ed., lowa State Univ. Press, Ames, lowa, USA.

Stork, P.O., Potgieter, J.P., Van den Heever, E., Niederwieser, J.G. (2004). Garlic Production, Guide to Garlic Production in South Africa, Agricultural Research Council-Vegetable and Ornamental Plant Institute, Roodeplaat, Pretoria.

Teklu Erkosa, Teklewold Hailemariam. (2009). Agronomic and economic efficiency of manure and urea fertilizers use on Vertisols in Ethiopian Highlands. Agricultural Science in China 8(3): 352-360.

Tisdale, S.L., Nelson, W.L. (1985). Soil fertility and fertilizers, $3^{\text {rd }}$ Ed. Macmillan Publishing Co. Inc., New York and Collico-Macmillan Publishers, London.

Van den Heever, E. (2006). Influence of growth stage and fertilization on the antifungal property of Tulbaghia violaea (Harv.) extracts. M.Sc. Thesis, Agricultural University of Free State, Bloemfontein.

Wolf, B. (1982). A comprehensive system of leaf analysis and its use for diagnosing crop nutrient status. Communications in Soil Science and Plant Analysis 13:1035-1059.

Yoldas, F., Safak, C., Nilgun, M., Bihter, C.E. (2011). Effect of organic and inorganic fertilizers on yield and mineral content of onion (Allium cepa L.). African Journal of Biotechnology 10(55): 11488-11492.

Zaman, M.S., Hashem, M.A., Jahiruddin, M., Rahim, M.A. (2011). Effect of Nitrogen for Yield Maximization of Garlic in Old Brahmaputra Flood Plain Soil. Bangladesh Journal of Agricultural Research 36(2): 357-367. 